Howhed when

NOV 12 999

\title{
BIOTECHNOLOGY AND GENETIC OPTIMIZATION OF FAST-GROWING HARDWOODS
}


The New York State Energy Research and Development Authority (Energy Authority) is responsible for the development and use of safe, dependable, renewable and economic energy sources and conservation technologies. It sponsors energy research, development anci demonstration (RD\&D) projects and financing programs designed to help utilities and other private companies fund certain energy-related projects. The Energy Authority is a public benefit corporation which was created in 1975 by the New York State Legislature.

In working toward these goals, the Energy Authority sponsors research, development and demonstration projects in two major program areas: Energy Efficiency and Economic Development, and Energy Resources and Environmental Research.

Under its financing program, the Energy Authority is authorized to issue tax-exempt bonds to finance certain electric or gas facilities and special energy projects for private companies.

The Energy Authority also has responsibility for constructing and then operating facilities for the disposal of low-level radioactive wastes produced in New York State. The generators of these wastes ultimately will bear the costs of the construction of these facilities.

A 13-member board of directors governs the Energy Authority, with William D. Cotter, Commissioner of the State Energy Office, serving as Chairman of the Board and Chief Executive Officer. Irvin L. White, President of the Energy Authority, manages its programs, staff and facilities.

The Energy Authority derives its basic RD\&D revenues from an assessment levied on the intrastate sales of New York State's investor-owned electric and gas utilities.

Additional RD\&D funds come from the investment of retained earnings, as well as from an annual contribution from the New York Power Authority.

The Energy Authority's RD\&D program is also supported by funds from a variety of cosponsors, including utilities, universities, industries, private engineering and scientific research firms, local governments, and State and Federal agencies.

For further information on the Energy Authority's programs, contact the Department of Communications, New York State Energy Research and Development Authority, phone (518) 465-6251, extension 272.

State of New York Mario M. Cuomo, Governor
Energy Research and Development Authority William D. Cotter, Chairman Irvin L. White, President 


\title{
BIOTECIINOLOGY AND GENETIC OPTIMIZATION \\ OF FAST-GROWING HARDWOODS
}

\author{
Final Report \\ NYSERDA- $-91-8$ \\ TI92 002650 \\ Prepared for: \\ NEW YORK STATE \\ ENERGY RESEARCH AND DEVELOPMENT AUTHORITY
}

Project Manager

Jeffrey M. Peterson

and

\section{GAS RESEARCH INSTITUTE}

Project Manager

Dan Dolenc

and

NEW YORK GAS GROUP

Project Manager

Robert Meade

Prepared by:

NPI, INC.

417 Wakara Way

Salt Lake City, Utah 84108

Principal Investigators

Stephen Garton

Eve Syrkin-Wurtele

Helen Griffiths

Jay Schell

Lisa Van Camp

Katrina Bulka

884-ERER-NRBC-86

Energy Authority

Report 91-8 


\section{NOTICE}

This report was prepared by NPI, Inc. in the course of performing work contracted for and sponsored by the New York Statc Energy Research and Development Authority, the Gas Research Institute, and the New York Gas Group (hereafter the "Sponsors"). The opinions expressed in this report do not necessarily reflect those of the Sponsors or the State of New York, and reference to any specific product, service, process, or method does not constitute an implied or expressed recommendation or endorsement of it. Further, the Sponsors and the State of New York make no warranties or representations, expressed or implied, as to the fitness for particular purpose or merchantability of any product, apparatus, or service, or the usefulness, completeness, or accuracy of any processes, methods, or other information contained, described, disclosed, or referred to in this report. The Sponsors, the State of New York, and the contractor make no representation that the use of any product, apparatus, process, method, or other information will not infringe privately owned rights and will assume no liability for any loss, injury, or damage resulting from, or occurring in connection with, the use of information contained, described, disclosed, or referred to in this report.

First Printing: October 1991 
A biotechnology research program was initiated to develop new clones of fastgrowing populus clones resistant to the herbicide glyphosate and resistant to the leaf-spot and canker disease caused by the fungus septoria musiva. Glyphosate-resistant callus was selected from stem segments cultured in vitro on media supplemented with the herbicide. Plants were regenerated from the glyphosate-resistant callus tissue. A portion of plants reverted to a glyphosate susceptible phenotype during organogenesis. A biologically active filtrate was prepared from $\underline{S}$. musiva and influenced fresh weight of Populus callus tissue. Disease-resistant plants were produced through somaclonal variation when shoots developed on stem internodes cultured in vitro. Plantlets were screened for disease symptoms after spraying with a suspension of fungal spores. A frequency of 0.83 percent variant production was observed.

Genetically engineered plants were produced after treatment of plant tissue with Agrobacterium tumefasciens strains carrying plasmid genes for antibiotic resistance. Transformants were selected on media enriched with the antibiotic, kanamycin. Presence of foreign DNA was confirmed by Southern blot analysis. Protopiasts of poplar were produced but did not regenerate into plant organs. 
CONTENTS

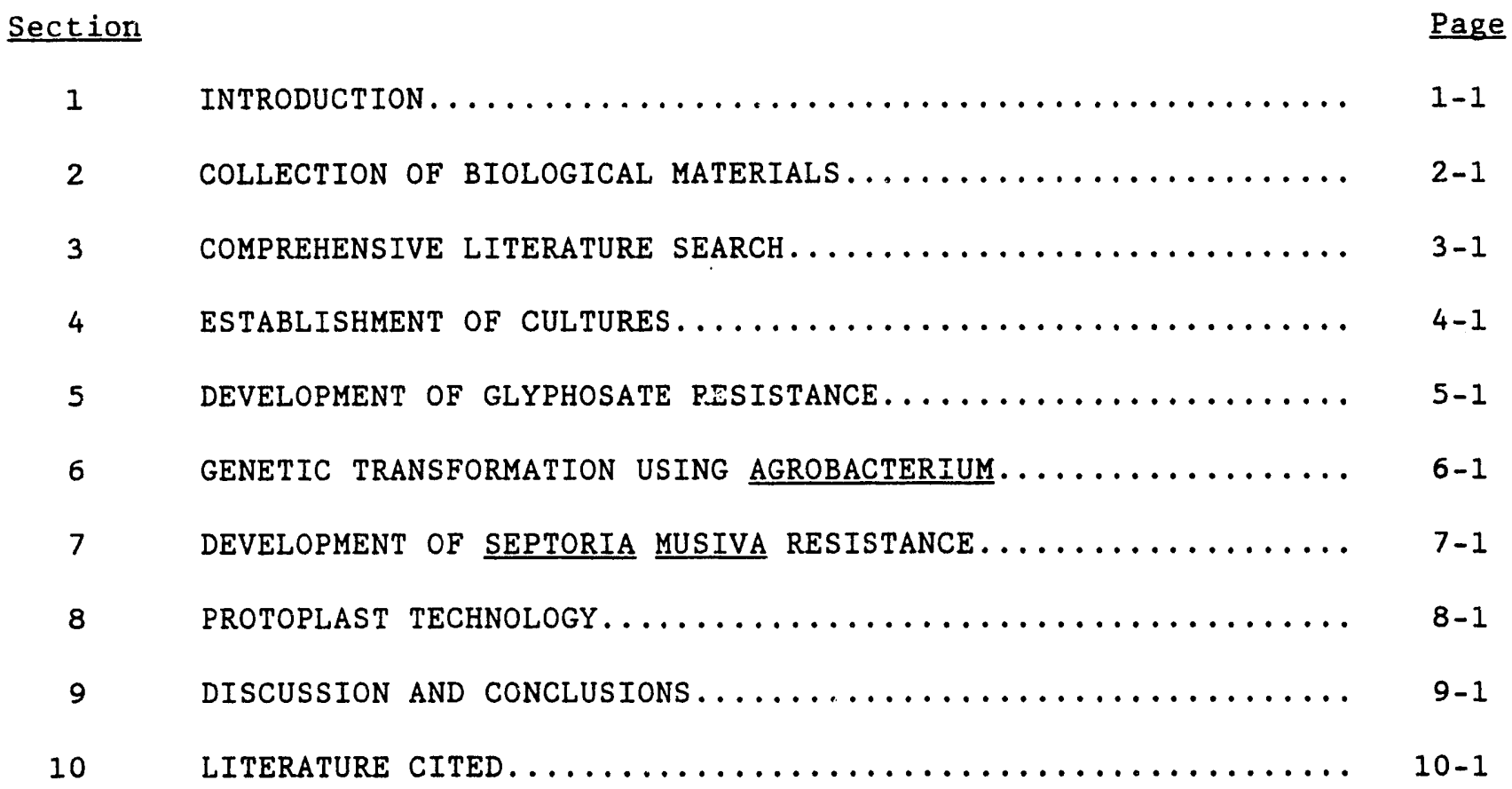




\section{ILLUSTRATIONS}

Figure

Page

4-1 Diagram of Plant Regeneration Routes from Populus Stem Tissue. 4-2

4-2 Diagram of Micropropagation from Shoot Buds of Populus...... 4-4

5-1 Protocol for Selection against Glyphosate............ 5-4

5-2 Effects of glyphosate in the culture medium on growth of

shoots regenerated from resistant and susceptible callus..... 5-8

6-1 General Protocol for Genetic Engineering of Poplar......... 6-2

6-2 Effect of Genetic Transformation on Callus Tissue Growth

from Poplar Stem Segments Cultured In Vitro in the

Presence of Kanamycin......................... $6-6$

6-3 Southern Blot of Digested NDA from Control and Transformed Poplar Probed with Radiolabeled DNA from Plasmid PTiA6C19+.... 6-8

6-4 Representation of Wild-Type (Upper) and Binary Vector

(Lower) Plasmids of $\underline{A}$. Tumefasciens................... 6-9

7-1 Protocol for Selection Against Septoria.............. 7-2

7-2 Lesions on Leaves from 4 Poplar Clones after Inoculation

with a Spore Suspension of $\underline{\mathrm{S}}$. Musiva................ 7-6

7-3 $\quad$. Musiva in Liquid Culture Medium................. $7-11$

8-1 General Protocol for Isolation and Culture of Protoplasts.... 8-1 
5-1 Effect of Glyphosate on Weight of Callus Formed by Stem Segments of Clones DTAC32 and NM2................. $5-2$

5-2 Effect of Glyphosate on Shoot Growth and Quality in Cultures of Clone NM6........................ 5-3

5-3 Mean Shoot Number Regenerated per Explant from Stem Segments of Four Populus Clones from Media Enriched with Glyphosate................................... $5-5$

5-4 Mean Callus Growth from Stem Segments of Four Poplar Clones Cultured on Media Enriched with Various Levels of Glyphosate.. 5-6

5-5 Mean Shoot Regeneration from Poplar Callus after Five Months of Growth on Glyphosate Enriched Media............ 5-6

5-6 Analysis of Variance for Data from Glyphosate Tolerance in Selected Shoots........................... 5-7

5-7 Effect of Origin of Primary Shoot (Herbicide Tolerant or Control, Non-selected, Callus Tissue) on Multiplication of Poplar Shoots after 6 Weeks Culture on Media Amended with Various Concentrations of Glyphosate................. 5-9

5-8 Effects of Glyphosate Concentration on Number of Shoots Produced from a Single Primary Shoot after 6 Weeks of Culture on Media Supplemented with Various Concentrations of Herbicide................................ 5-10

5-9 Inventory of Populus Shoots Regenerated from Callus Tissue Produced on Media Containing 100 Micromolar Glyphosate........

Effect of Kanamycin on Multiplication in Cultures of NM6 Shoot-Tips................................ 6-3

6-2 Effect of Agrobacterium Strain and Kanamycin Concentration on Shoot Production from Stem Explants of DN66.............

6-3 Effect of Agrobacterium Strain, Concentration and Kanamycin in the Culture Medium on Mean Number of Shoots Produced

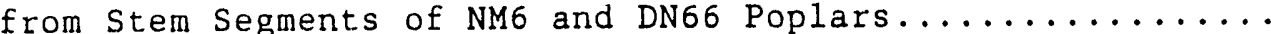

6-4 Effect of Agrobacterium Strain, Concentration, Co-cultivation Time, and Kanamycin in the Culture Medium on Mean Number of Shoots Produced from Stem Segments of NM6......

6-5 Effect of Agrobacterium Strain on Mean Number of Shoots Produced from Stem Segments of DN66. 
6-6 Effect of Kanamycin in the Culture Medium on Shoot Production from Agrobacterium Treatad Stem Segments of

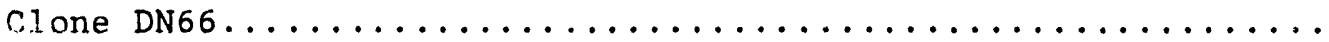

7-1 Arbitrary Scale for the Evaluation of Septoria Musiva

Symptoms in Greenhouse Plants...................... 7-3

7-2 Effect of Fungal Isolate on Mean Category Value...........

7-3 Effect of Clone on The Development of Disease Symptoms in Greenhouse Grown Plants......................... 7-4

7-4 Effect of Number of Days Post-inoculation on Development of Foliar Disease Symptoms in Greenhouse Grown Poplars....... 7-4

7-5 Effect of Clone and Fungal Isolate on the Severity of Foliar symptoms in Greenhouse Grown Poplars............... 7-5

7-6 Effect of Clone and Isolate on Percent of Stem and Petiole Sections Which Exhibited Lesions 16 Days aftor Treatment

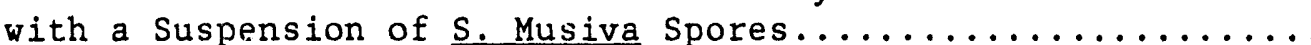

Effect of Clone and Isolate on Lesion Area, Measured in $\mathrm{mm}^{2}$, in Discs from Older Expanded Leaves after Treatment with

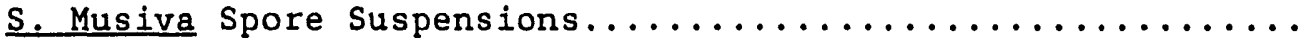

7-8 Effect of Clone and Isolate on Lesion Area, Measured in $\mathrm{mm}^{2}$, in Discs from Younger Expanding Leaves after Treatment with S. Musiva spore suspensions......................

7-9 Effect of Fungal Culture Filtrate Extract and Spores on Percentage of Leaf Discs Which Developed Disease-like Lesions.

7-10 Effect of Fungal Culture Filtrate Extracts on Fresh Weight c.f Callus Tissue from Clone NM4 after 16 Days Incubation......

7-11 Effect of Concentration of Fungal Culture Filtrate Extract on Fresh Weight of NM6 Stem Callus...................

7-12 Effect of Origin of Culture Filtrate Extracts on Fresh Weight Gain of DNl34 stem Calius...................

7-13 Effect of Concentration of $\mathrm{S}$. Musiva Culture Filtrate Preparation on Fresh Weight of DN134 Stem Callus...........

7-14 Effect of Clone on Fresh Weight Gain in Populus Callus Cultured in Media Amended with Liquid, Fungal, Culture

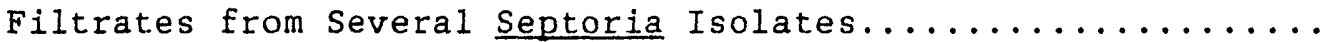

7-15 Effect of Septoria Isolate on Fresh Weight Gain in Populus Callus Cultured in Media Amended with Liquid, Fungal, Culture Filtrates............................ 
7-16 Effect of Dose of Liquid, Fungal, Culture Filtrate on Fresh Weight Gain of Populus Callus Cultured in Media Supplemented with Such Filtrates Prepared from Septoria Musiva Cultures... 7-18

7-17 Effect of Septoria Isolate Origin and Dose of Liquid culture Filtrate on Fresh Weight Gain of Populus Callus Cultured In Vitro on Media Supplemented with Filtrates...... 7-18

7-18 Effect of Clone on Fresh Weight Gain in Populus Callus Cultured in Media Amended with Fungal, Culture Filtrate Extracts from Several Jsolates of Septoria Musiva........... 7-20

7-19 Effect of Septoria Isolate on Fresh Weight Gain in Populus Callus Cultured in Media Amended with Fungal, Culture

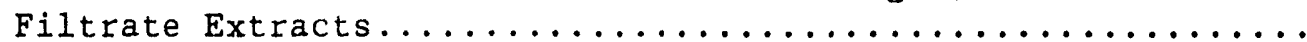

7-20 Effect of Dose of Fungal, Culture Filtrate Extract on Fresh Weight Gain of Populus Callus Cultured in Media Supplemented with Such Filtrates Prepared from Septoria Musiva Cultures....

7-21 Effect of Dose of Culture Filtrate Extract and Clone on Fresh Weight Gain of Populus Callus Cultured on Media

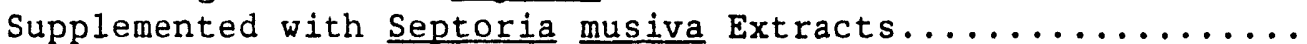


SUMMARY

This research and development program was initiated to address two major goals: the production of poplar trees resistant to the herbicide giyphosate, and production of plants with increased resistance to attack by the fungus Septoria musiva, the causal agent of a leaf-spot and canker disease. Additionally, genetic engineering was applied to poplar and attempts were made to culture and regenerate protoplasts derived from poplar tissues.

Poplar trees for the study were obtained from the Northeast through an arrangement with Canadian forestry professionals in Quebec province. Various isolates of the pathogenic fungus were obtained from a pathologist in the northern great plains region.

A selection method obtained the glyphosate resistance. Tissue cultures of poplar were transferred to media containing various concentrations of glyphosate. Occasionally, small colonies of tissue flourished in the presence of the herbicide. These colonies were assumed to have developed resistance and were induced to produce shoots, some of which were converted to whole plants. The plants were tested for resistance by treatment with glyphosate and were found to be susceptibie to typical commercial concentrations of the herbicide used to control weeds. Thus, the selection of callus tissues, which grew in the presence of glyphosate, did not produce a plant with the herbicide-resistant trait.

Two approaches were taken to produce poplars with increased ability to resist attack from the fungus septoria musiva. The first approach was similar to that employed to develop glyphosate resistance and was based on in vitro selection 
against a crude toxin obtained from cultures of the fungus. A biologically active extract was obtained from media in which the fungus had grown. The extract inhibited growth of poplar tissue when it was added to culture medium. This was a clear demonstration that in vitro selection was possible; however, the biologically active compound was difficult to produce, was essentially uncharacterized, and was not necessarily involved in disease development in the whole plant. Thus, a second opportunity for development of plants was investigated.

Previous work with poplar tissue cultures indicated that certain regenerated plants differed from the original donor plants. New variations were apparently created as a result of the tissue culture process. Such variation is termed somaclonal variation. Since variation can arise in tissue culture, large numbers of plants were regenerated from tissue cultures of several poplar clones. The plants were screened in the greenhouse by applying a spore suspension obtained from cultures of the fungus. Plants whose leaves showed no symptom development were retained as apparent variants and subjected to further treatment with fungal spores. Treatment of over 14,000 plants produced 153 plants with altered reaction to the fungal spores. A relatively high frequency of variant production was observed: however, disease development in field plantations is likely to be more complex than the simple, leaf symptom tests conducted in the greenhouse. Plant material was sent to a collaborator in New York State for observation of field performance of some of the new variants.

Recently, genetic engineering has emerged as an exciting new technology with the potential to improve plant performance through the incorporation of genes from different organisms into plants. New genes are typically introduced into plant 
tissue with the aid of a bacterium that carries the particular gene and can "inject" the gene into plant cells. The bacteria employed in genetic transfer are uslially fror the Agrobacterium family. The poplar work involved incorporating new genes for antibiotic resistance into cells of poplar tissue using Agrobacterium to carry the "new" genes. Genetically altered tissues were selectively cultured and new plants were eventually regenerated from these tissues. DNA samples from leaves of these plants were analyzed for the presence of genes from the hacterium. The results showed that the new genes were present in the plant tissues and that transfer of foreign genes was successful. Thus, the work demonstrated the feasibility of poplar improvement using genetic engineering methods.

Protoplasts, plant cells without cellulose walls, were produced from callus and leaf tissue. The protoplasts were cultured to produce small colonies of tissue but no organs were developed from these colonies. This successfully completed program has provided new plant material from clones well-adapted to the region, and has demonstrated the feasibility of applying genetic engineering methods to some of these same clones. The utility of cell selection methods for wholeplant improvemenc was not demonstrated using the herbicide-resistant trait. 
Section 1

INTRODUCTION

In response to proposal request number ER-96-85, Native Plants Incorporated (NPI) proposed a pioject for New York State Energy Research and Development Authority (NYSERDA), the Gas Research Institute (GRI) and the New York Gas Group (NYGAS). The successful proposal described a series of tasks designed to apply the techniques of modern biotechnology the following goals:

(i) creation of populus clones with resistance to the herbicide glyphosate;

(ii) creation of populus clones with resistance to the leaf spot and canker disease caused by the fungus Septoria musiva;

(iii) development of an efficient protocol for introduction of "new" genes into poplar clones using genetic engineering technology and

(iv) investigation of the feasibility of developing poplar plants from isolated protoplasts.

Much progress was made during the first year and was documented in the first status report submitted in 1987 . Building on this foundation effort during the second year has focused on the following areas:

o development of glyphosate resistance;

- development of a transformation (genetic engineering) system;

o development of Septoria resistance, and

o protoplast isolation and culture. 
The following sections describe the work, the results, and the significance of the findings in relation to the general field of plant biotechnology. 
Section 2

COLLECTION OF BIOLOGICAL MATERIAL

Twenty-five hardwood cuttings of each of 18 populus clones were obtained from Mr. Brian Barkley of the fast-growing forest technology development group of the Ontario Ministry of Natural Resources. The following clones were received from the Canadian group:

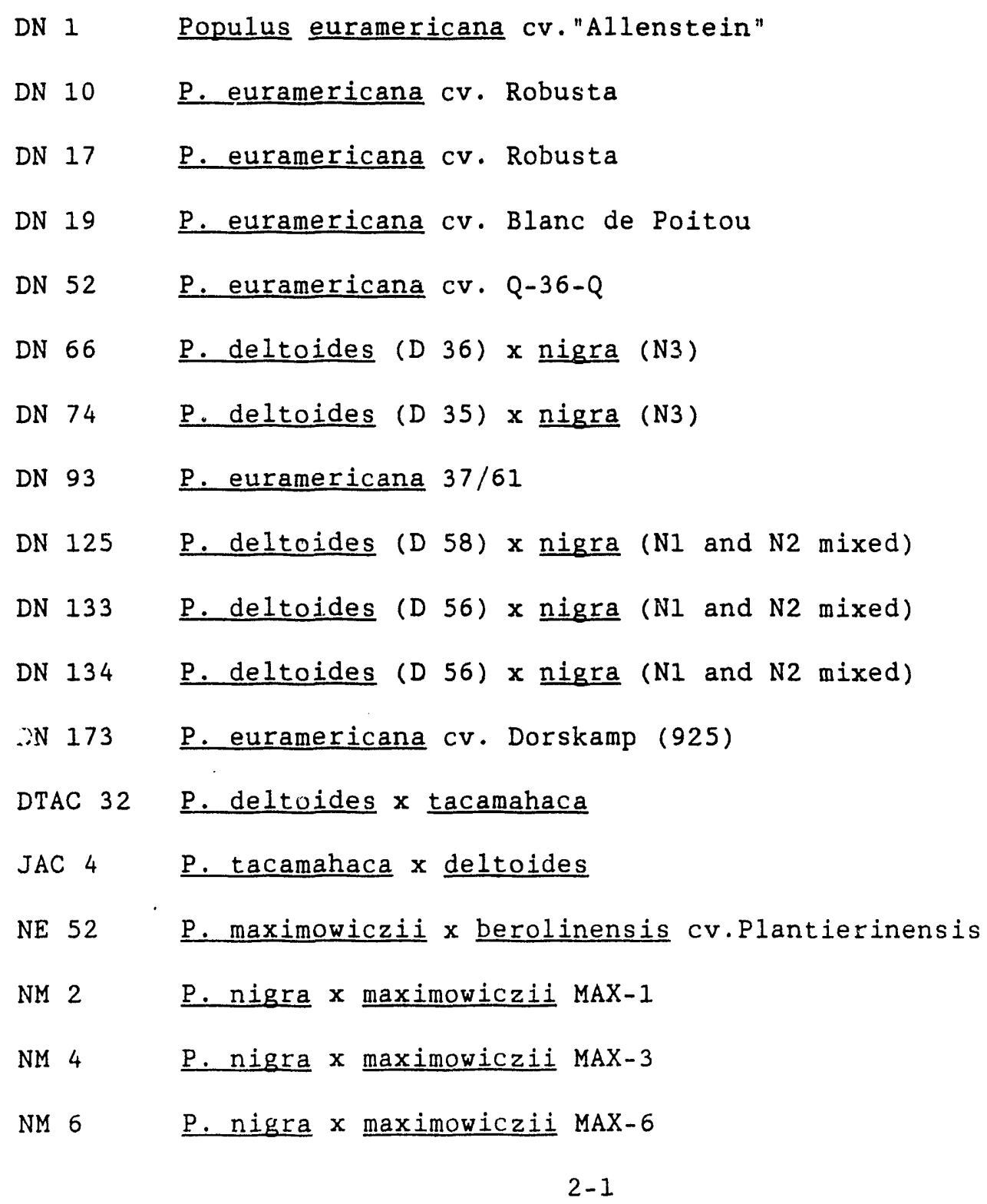


In addition to this material, five poplar clones were obtained from Mr. W. Berguson of the University of Minnesota. These clones were collected based on their susceptibility to infection by the fungus septoria musiva. The plant materials obtained included:

$\begin{array}{lll}\text { O NE 206 } & \text { Extremely susceptible } \\ 0 & \text { NE } 345 & \text { Moderately susceptible } \\ 0 & \text { L } 296 & \text { Extremely susceptible } \\ \text { o } & \text { DN } 29 & \text { Very susceptible } \\ \text { O } & \text { Raverdeau } & \text { Very resistant }\end{array}$

On receipt, cuttings were established as plants in NPI research greenhouses where they were grown up to provide additional cuttings for whole-plant studies and to provide explants for in vitro cultures.

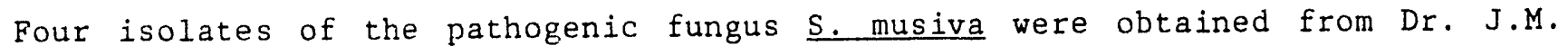
Krupinsky, with the United States Department of Agriculture in Mandan, Nortn Dakota. Isolates 83-5348, 83-5872, 83-5913 and 83-5948 were cultured onto maintenance media. 
A computer-assisted search of published and abstracted literature used the following keywords:

1. Poplar or Cottonwood or Populus

2. 1 and Septoria musiva

3. 1 and Agrobacterium

4. 1 and tissue culture or in vitro

5. 1 and glyphosate

6. 1 and herbicide

7. plant transformation

The search revealed some 6000 titles. Approximately 70 of these appeared relevant and were obtained through university libraries. A bibliography is included with this report in section 10 . 


\section{Section 4 \\ ESTABLISHMENT OF CULTURES AND OPTIMIZATION \\ OF TISSUE CULTURE PROTOCOLS}

Previously published work with tissue culture and micropropagation of Populus spp. indicated that various approaches to plant regeneration have been successfully applied (Mathes 1964, Winton 1970, Venverloo 1973, Chalupa 1974, Christie 1978, Mehra and Cheema 1980, Ahuja 1984, Douglas 1985). Three plant-r ageneration protocols were optimized for application in this project: direct development of shoots from stem segments; development of shoots from callus tissue produced on stem segments and production of shoots from in vitro cultured buds. The first two methods are represented diagrammatically in Figure 4-1.

\section{CALLUS CULTURE AND ADVENTITIOUS SHOJT FORMATION}

Optimal conditions for both callus formation and shoot regeneration were determined for the poplar clones. Stem sections from young green shoots, $10-30 \mathrm{~cm}$ behind the apex, were disinfested by hypobaric soaking in a 10 percent solution of commercial bleach for 10 minutes. Segments were cut into $2-3 \mathrm{~mm}$ slices and placed into petri plates containing $20 \mathrm{ml}$ aliquots of MS medium (Murashige and Skoog 1962) supplemented with various concentrations of plant growth regulators. Direct adventitious shoot production was stimulated by culture of stem segments on a medium supplemented with $0.3 \mathrm{mg}$ per liter benzyladenine (BA) while callus production was induced by culture on a medium enriched with $0.3 \mathrm{mg}$ per liter BA and $0.2 \mathrm{mg}$ per liter 2,4-dichlorophenoxyacetic acid $(2,4-D)$. When callus tissue was transferred to medium supplemented with either 0.2 or $0.3 \mathrm{mg}$ per liter BA, shoots were produced from the callus. Experiments were carried out with stem segments of several clones and results indicated that different clones had 

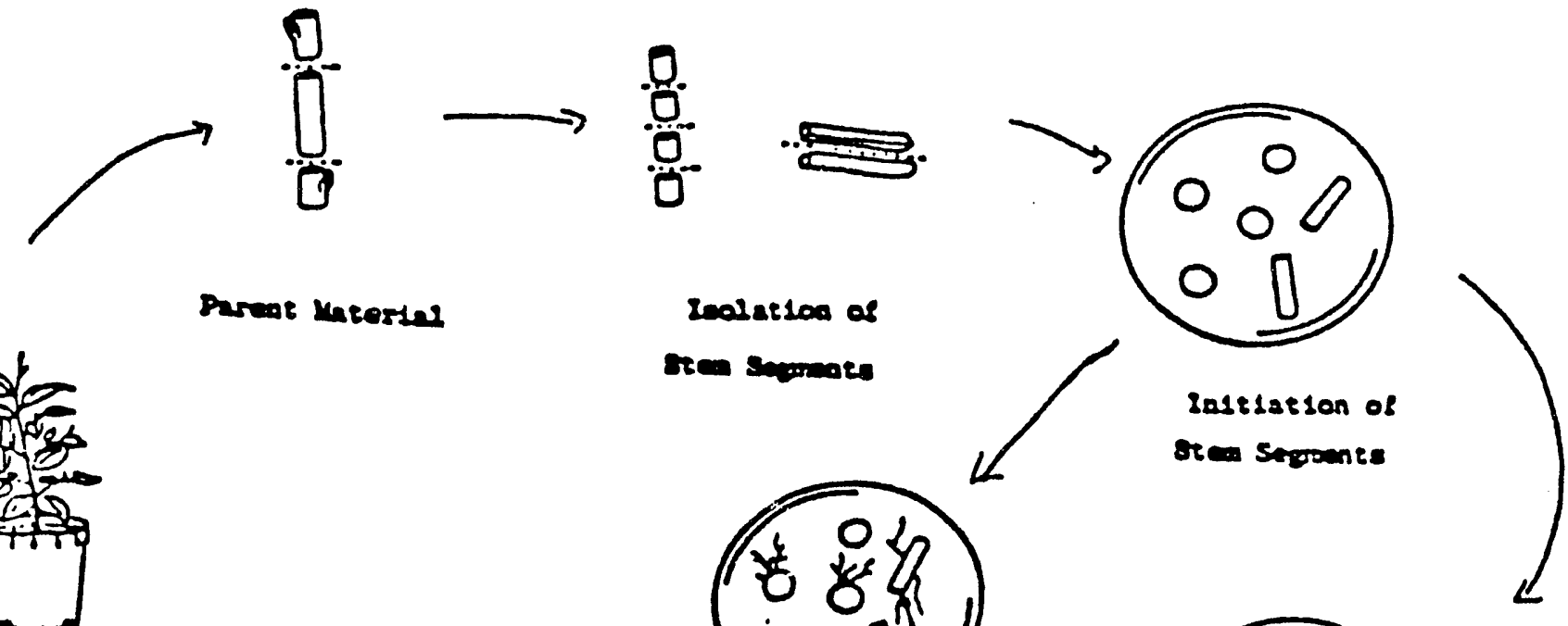

plast Entablebad in Soll

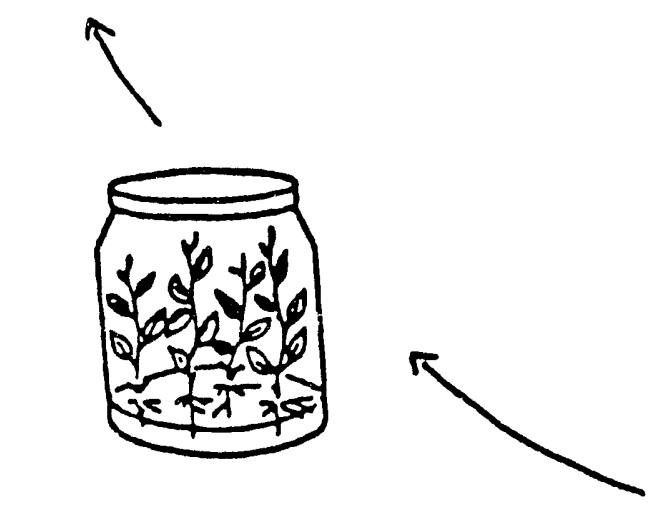

Pleatlet Doveloppeat by Rooting of Inolated stopes
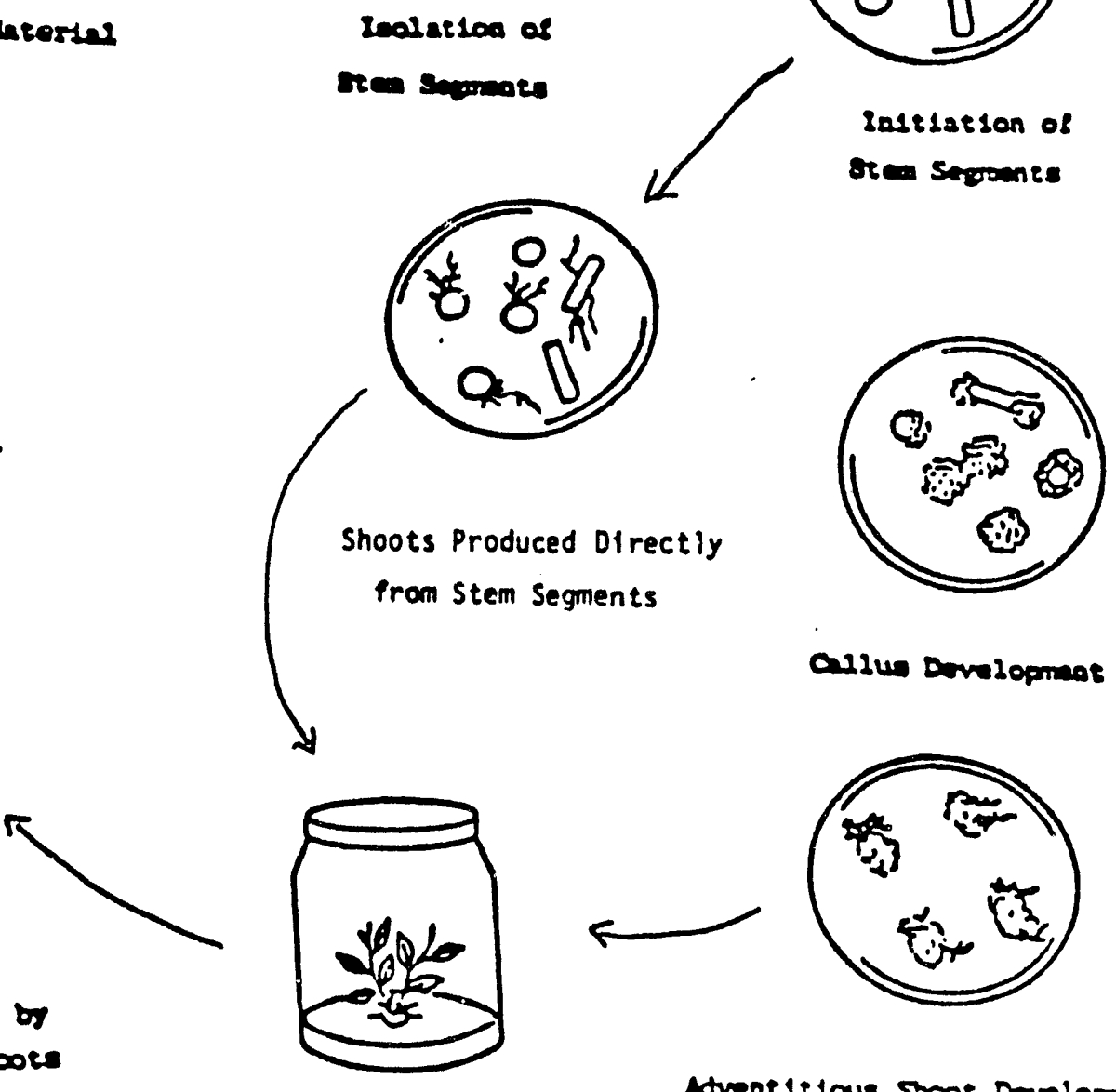

Oellun Dorvelopmate

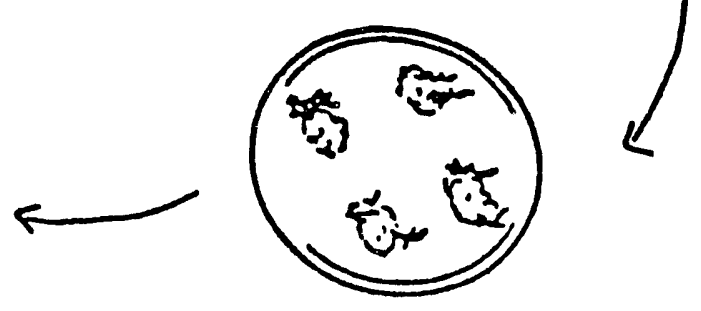

Advest 1t lous sooot Development stom Callus rese

eroarly of sooen

Figure 4-1. Diagram of Plant Regeneration Routes from Populus Stem Tissue 
different capacities to produce shoots and callus. However, such a large collection of plant material was established that only those clones that were most responsive to in vitro manipulation were selected. These clones provided the raw material for the subsequent work with glyphosate and $\underline{\text { s. musiva. }}$

\section{MICROPROPAGATION OF POPLAR}

Axillary or lateral buds, and shoot-tips from soft, rapidly growing shoots, provide the best material for initiation of shoot-tip cultures for micropropagation. This process is represented in Figure 4-2. Stems were collected from stock plants. Leaves were removed and stem segments were disinfested. After rinsing, nodal segments and shoot tips were removed and placed into culture vessels containing aliquots of medium. The basal culture medium consisted of the salts and organic constituents of the woody plant (WP) medium (Lloyd and McCown 1980) supplemented with BA 0.1-0.5 mg/L., sucrose at 3 percent, and agar at 0.6-0.7 percent. The $\mathrm{pH}$ of the medium was adjusted to 5.75 prior to autoclaving at $121 \mathrm{C}$ for 30 minutes. 


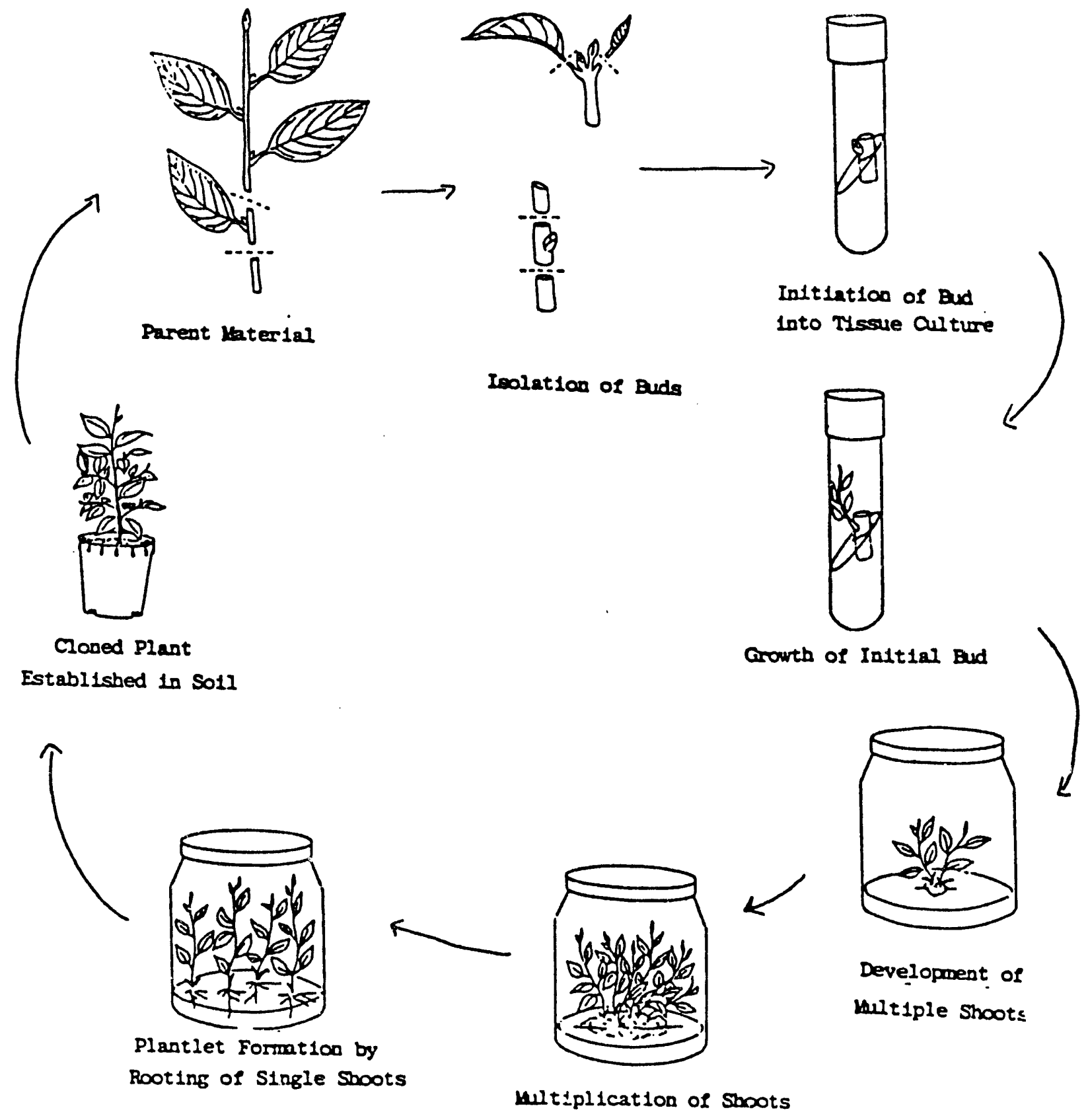

Figure 4-2. Diagram of Micropropagation from Shoot Buds of Populus 
Cultures were incubated at 23-27 C under 16 hours of radiation from a source that emitted 30-90 microeinsteins per square meter per second.

Shoot growth from existing buds was evident after two-four weeks in culture. After 25-35 days, the plant material was transferred to a fresh aliquot of similar medium. Shoot proliferction in cultures of Populus spp. occurred through the enhancement of axillary branching in buds present on the original explant. This type of growth resulted in the formation of a mass of stem tissue from which several elongating shoots arose. These clumps of shoots and associated basal tissue were the basic units used for in vitro multiplication. A typical culture is shown in Figure 4-3.

These "clumpy" structures formed from the initial explant during the second, third, or fourth in vitro cycle. After the formation of such structures, multiplication was achieved by division of the large clumps into several smaller units that were transferred to separate culture vessels. At the same time, elongated shoots that formed on the original clump were removed and either dissected into three-four node segments and placed on aliquots of multiplication medium, or the shoots were used to develop plantlets.

Rooting of individual shoots was achieved by one of two methods. Using the first method, plantlet formation was achieved by rooting shoots in vitro on WP medium supplemented with indolebutyric acid at one-three $\mathrm{mg} /$ liter. Shoots at least 1.5 $\mathrm{cm}$ long were removed from multiplying cultures, small leaves were removed from the bottom third of the stem and the shoot was stuck into the rooting medium. Roots appeared on the stems within two-three weeks. 


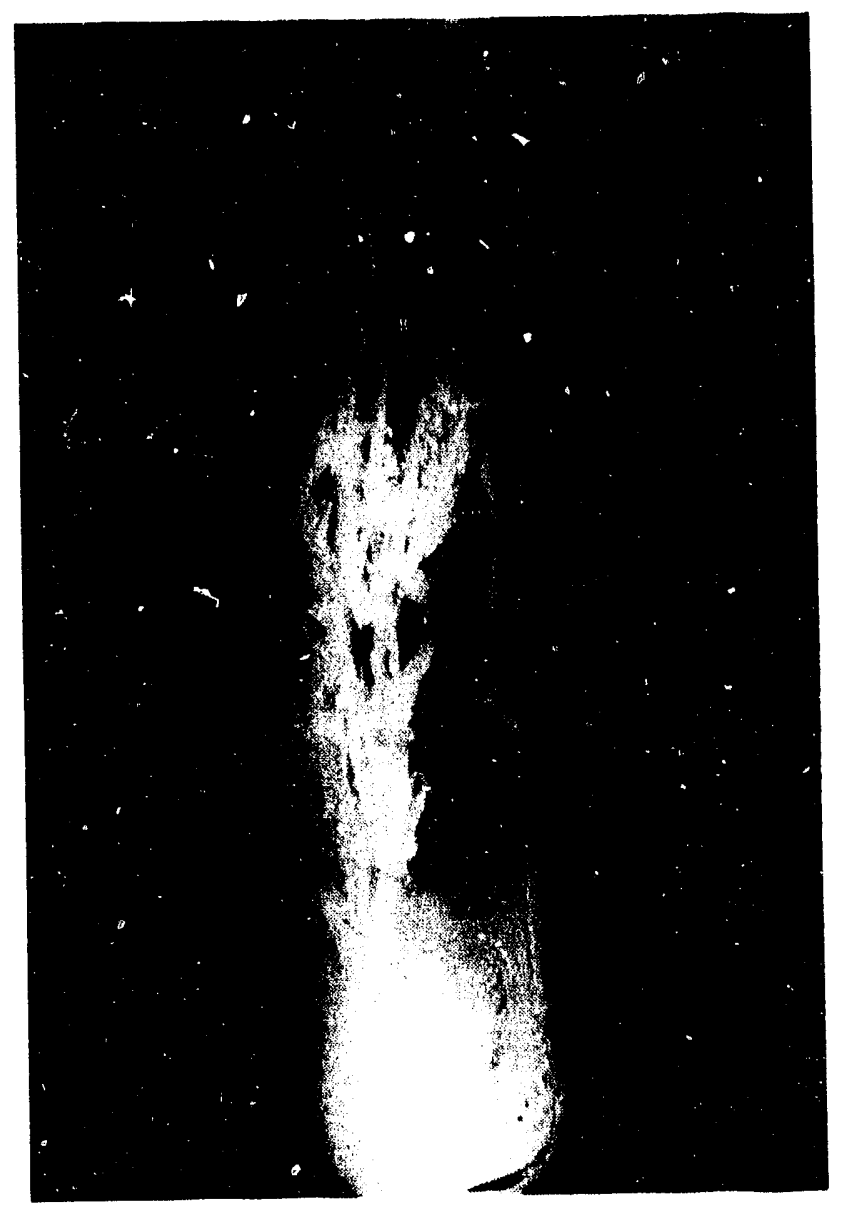

Figure 4-3. Multiplying shoot-tip culture of clone NM4 after two months incubation When root growth was apparent, plantlets were transferred to soil and cultivated under nursery conditions. Plantlets were removed from the culture vessels and potted into containers filled with a well-draining, pasteurized medium. After a thorough watering, the containers were placed in a warm, humid, shaded, environment to start the acclimatization process. Acclimatization typically involves integrated manipulation of temperature, light intensity and relative humidity. By close observation of the plants coupled with appropiate manipulation of the 
environment, acclimatization was achieved during a two-four week period.

The second method of plantlet formation from in vitro-derived shoots involved rooting and sinultaneous soil acclimatization. Shoots at least $1.5 \mathrm{~cm}$ long were removed from multiplying cultures and transferred directly to containers filled with a potting medium. Direct soil transfer of unrooted shoots was a useful technique in micropropagation of poplar, but a high degree of environmental control was required to ensure that the majority of shoots formed roots and became successfully established as plants. Micropropagation protocols were established for most of the clones collected. 
Section 5

DEVELOPMENT OF GLYPHOSATE RFSISTANCE

Novel plant mutants have been isolated by the application of selective growth conditions to cultured cells (Chaleff 1981) and unique phenotypes have been isolated by selection of plant tissue in situ (Carlson 1984). Herbicideresistant, mutant cells have been identified in tobacco, celery and carrot by cultivation of cells in media containing various levels of herbicide (Chaleff 1983; Merrick and Collin 1981; Nafziger et al. 1984). In particular, glyphosatetolerant plants were regenerated from cells selected in vitro. Induced tolerance to the herbicide glyphosate was expressed in regenerated tobacco plants (Singer and McDaniel, 1985).

An extensive series of experiments was initiated to determine the responses of in vitro-cultured Populus tissues to glyphosate. Since uptake and metabolism of herbicides can be influenced by target tissue and stage of plant development, the effects of glyphosate on callus growth and shoot regeneration were examined to determine the optimal range of glyphosate for use in selection studies. These experiments were conducted with clone DTAC-32 and clone NM2. Dose responses were generated by in vitro culture of stem explants on media enriched with $0,10,100$, 300,1000 , and 3000-micromolar glyphosate. After 30 days in culture, callus growth and shoot regeneration were evaluated in 12 replicates of each clone in each glyphosate concentration in each medium. Results are presented in Table 5-1. 
Table 5-1

EFFECT OF GLYPHOSATE ON WEIGHT OF CALLUS FORMED BY STEM SEGMENTS OF CLONES DTCA32 AND NM2

\begin{tabular}{|c|c|c|}
\hline $\begin{array}{c}\text { Micromolar Concn. } \\
\text { of Glyphosate }\end{array}$ & $\begin{array}{c}\text { Fresh Weight } \\
\text { NM2 }\end{array}$ & per Explant $(g)^{\text {a }}$ \\
\hline 0 & $0.21 \mathrm{a}$ & $0.36 \mathrm{a}$ \\
\hline 10 & $0.13 \mathrm{~b}$ & $0.15 \mathrm{~b}$ \\
\hline 100 & $0.08 \mathrm{bc}$ & $0.12 \mathrm{bc}$ \\
\hline 1000 & $0.03 \mathrm{c}$ & $0.07 \mathrm{bc}$ \\
\hline 3000 & $0.03 \mathrm{c}$ & $0.05 \mathrm{bc}$ \\
\hline 10000 & $0.01 \mathrm{c}$ & $0.03 \mathrm{c}$ \\
\hline
\end{tabular}

a/ Means within a column followed by a different letter are significantly different by Duncan's multiple range test at $p=0.05$.

Since the two clones differed in susceptibility to glyphosate, it was not possible to choose a single concentration to induce a 50 percent or 95 percent growth inhibition.

A comparative study was undertaken to determine the sensitivity of cultured populus microshoots to glyphosate. Shoot-tip cultures of clone NM6 were transferred to multiplication medium enriched with 0,100 , and 300 micromolar glyphosate. Multiplication and shoot quality were assessed after 30 days of culture, when microshoots were subcultured onto fresh aliquots of similar medium and evaluated after a further 30-day cycle. 
Table 5-2

EFFECT OF GI.YPHOSATE ON SHOOT GROWTH AND QUALITY IN CULTURES OF CLONE NMG

\begin{tabular}{|c|c|c|}
\hline $\begin{array}{l}\text { Glyphosate Concentration } \\
\text { (micromolar) }\end{array}$ & $\begin{array}{l}\text { Growth and } \\
1^{s} \text { t CYCLE }\end{array}$ & $\begin{array}{l}y \text { Index a/ } \\
\text { 2nd CYCLE }\end{array}$ \\
\hline 0 & 4.0 & 4.0 \\
\hline 100 & 2.9 & 0 \\
\hline 300 & 1.8 & 0 \\
\hline
\end{tabular}

Results are presented in Table 5-2. and indicate that 100-micromolar glyphosate concentrations consistently inhibited growth cver the f_rst 30 days and death of the explants during the second 30-day period. Thus, microshoot growth in vitro is more glyphosate-sensitive than callus growth or shoot regeneration.

It is important to know the glyphosate sensitivities of greenhouse-grown plants of the clones included in the selection program. It is essential to determine the appropriate range of glyphosate concentrations with which to screen regenerated clones selected in vitro. Studies were initiated to determine tolerance of greenhouse-grown plants. Uniform plants of clone DN66 were sprayed with $0,0.2$, 2.0, and 20.0 millimolar glyphosate solutions. Plant quality and overall toxicity symptoms were evaluated after two weeks. The results indicated that treatment with $2.0,10.0$ and 20.0 millimolar glyphosate was an appropriate range of concentrations for application in future studies. 


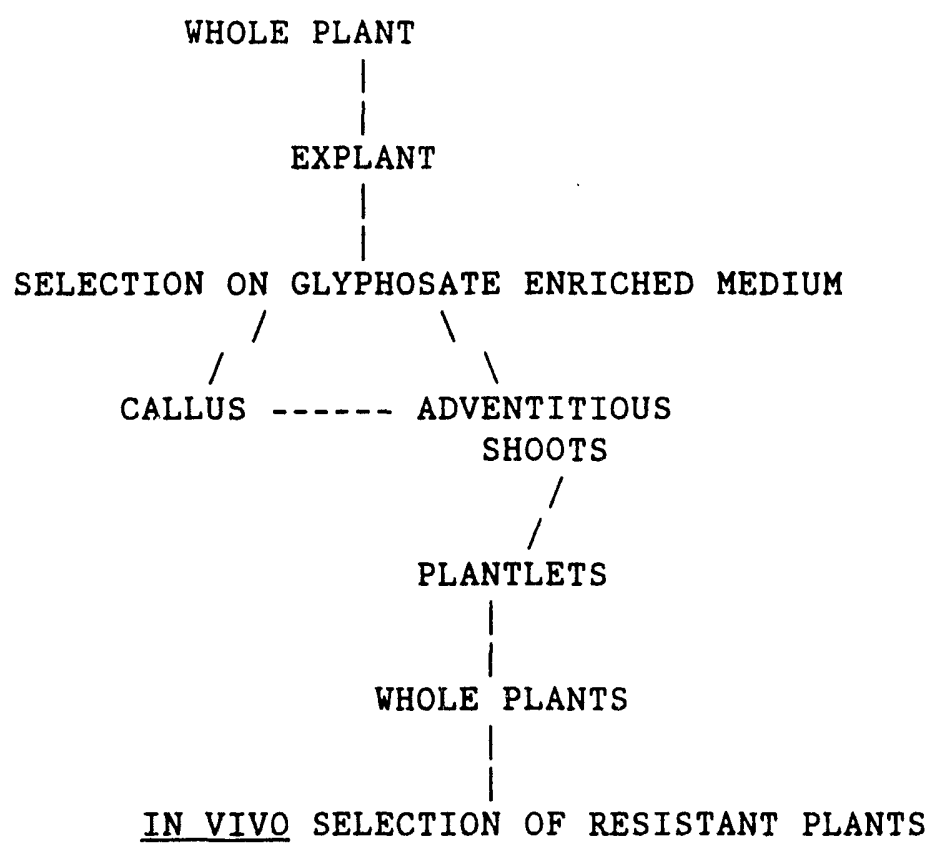

Figure 5-1. Protocol for Selection against Glyphosate

Using information obtained from initial experiments, a general protocol for selection of glyphosate-resistant cells and tissues was developed and is represented diagramatically in Figure 5-1. Clones NM2, NM4 and DN66 were selected as target clones based on three considerations: capacity for callus production; capacity for adventitious regeneration of shoots, and response to glyphosate in the culture medium. Stem cross-sectional segments were placed on callus-forming and shoot-forming media containing 0,100 , or 300 micromolar glyphosate. Shoot and callus formations in each clone were evaluated after 60 days of culture by observation of 24 replicate stem segmeats per glyphosate concentration. Glyphosate-resistant callus was formed in the three clones. 
Clones NM2, NM4, NM6, and DN66 were selected as target clones based on three considerations: capacity for callus production; capacity for adventitious regeneration of shoots, and response to glyphosate in the culture medium. Stem cross-sectional segments were placed on callus-forming and shoot-forming media containing 0,100 , or 300 micromolar glyphosate. Shoot and sallus formations in each clone were evaluated after 60 days of culture by observation of 24 replicate stem segments per glyphosate concentration. Glyphosate in the culture medium completely inhibited adventitious shoot production in the four clones. Herbicideresistant callus was formed at the lower concentration from explants of all clones, but only NM4 explants produced callus at the higher concentration (Tables $5-3$ \& $5-4)$.

Table $5 . .3$

MEAN SHOOT NUMBER ${ }^{a /}$ REGENERATED PER EXPLANT FROM STEM SEGMENTS OF FOUR POPULUS CLONES FROM MEDIA ENRICHED WITH GLYPHOSATE

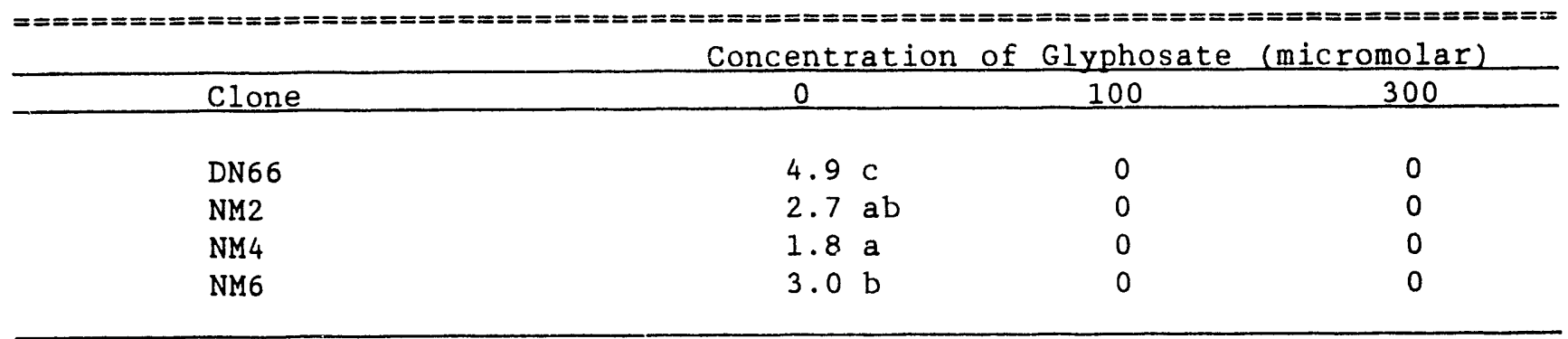

a/Means calculated from 24 replicates; those within columns followed by different letters are significantly different at $p=0.05$ by Duncan's New Multiple Range Test. 
Table $5-4$

MEAN CALLUS GROWTH ${ }^{2}$ FROM STEM SEGMENTS OF FOUR POPLAR CLONES CULTURED ON MEDIA ENRICHED WITH VARIOUS LEVELS OF GLYPHOSATE

\begin{tabular}{|c|c|c|c|}
\hline Clone & 0 & 100 & 300 \\
\hline DN66 & $0.12 \mathrm{a}$ & $0.25 a$ & $0.0 \mathrm{a}$ \\
\hline NM2 & $1.90 \mathrm{~b}$ & $1.33 \mathrm{~b}$ & $0.0 \mathrm{a}$ \\
\hline NM4 & $3.16 \mathrm{c}$ & $1.80 \mathrm{~b}$ & $1.05 \mathrm{~b}$ \\
\hline NM 6 & $1.54 \mathrm{~b}$ & $0.30 \mathrm{a}$ & $0.0 \mathrm{a}$ \\
\hline
\end{tabular}

a/Mean scores calculated from 24 replicates per treatment.

b/Means within columns followed by different letters are significantly different at $p=0.05$ by Duncan's New Multiple Range Test.

Calli from clones NM2, NM4, and DN66 were maintained by month1y subculture onto similar medium over a period of five months. Samples of this herbicide-resistant callus tissue were transferred to shoot-production media supplemented with 100micromolar glyphosate. After six weeks, shoot regeneration was observed from calli of clones NM2 and DN66 grown on media enriched with 100 micromolar glyphosate. No shoots regenerated from calli of clone NM4 or calli of clones NM4 and DN66 that originated on media containing 300-micromolar glyphosate. Mean number of shoots per callus clump and total numbers of shoots produced are presented in Table 5-5.

Table 5-5

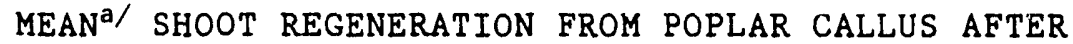

FIVE MONTHS OF GROWTH ON GLYPHOSATE-ENRICHED MEDIA

\begin{tabular}{|c|c|c|c|}
\hline & Concent & $f G 1 Y$ & (micromolar) \\
\hline Clone & 0 & 100 & Total Shoots \\
\hline NM2 & $0.87 \mathrm{a}$ & 0.0 & 27 \\
\hline DN66 & $1.16 \mathrm{a}$ & 0.0 & 7 \\
\hline NM4 & 0.0 & 0.0 & 0 \\
\hline
\end{tabular}

a/Means calculated from at least six replicates; those within columns followed by different letters are significantly different at $p=0.05$ by Duncan's New Multiple Range Test. 
After regeneration on media containing herbicide, microshoots from a particular callus clump were assigned a label and transferred to aliquots of multiplication medium containing no herbicide. Propagation was allowed to proceed for 12 or 16 weeks to increase the pool of glyphosate-resistant material.

Samples of shoots from seven of the glyphosate-resistant callus lines were transferred to multiplication media containing either $0,25,50,75$, or 100 micromolar glyphosate. Shoots regenerated from non-selected callus were transferred to similar media as a control for the experiment. After six weeks, the numbers of shoots produced by each primary explant were counted from each replicate vessel for each shoot-line in each medium treatment. The data were summarized using analysis of variance techniques (Table 5-6).

Table 5-6

ANALYSIS OF VARIANCE FOR DATA FROM GLYPHOSATE TOLERANCE IN SELECTED SHOOTS

\begin{tabular}{lcrrr}
\hline Source & Degrees of Freedom Surn of Squares & Mean Square & F Ratio \\
\hline & 7 & 78.2 & 11.2 & 3.4 \\
Origin & 4 & 1260.6 & 315.1 & 96.2 \\
Treatment & 28 & 86.3 & 3.1 & 0.9 \\
Origin * Trt & 300 & 983.2 & 3.3 & \\
Error & 339 & 2408.3 & & \\
Total & &
\end{tabular}

Single Degree of Freedom Contrasts for Effect Termed-Origin

\begin{tabular}{ccc}
\hline Contrast & Mean Square & Ratio \\
\hline non-selected vs B111 & 22.3 & 6.8 \\
non-selected vs B113 & 48.1 & 14.7 \\
non-selected vs Al13 & 17.0 & 5.2 \\
non-selected vs A112 & 3.3 & 1.0 \\
non-selected vs B119 & 2.0 & 0.6 \\
non-selected vs A114 & 7.4 & 2.2 \\
non-selected vs B116 & 0.4 & 0.1 \\
\hline
\end{tabular}


Single Degree of Freedom Contrasts for Effect-Termed Treatment

\begin{tabular}{lcc}
\hline Contrast & Mean Square & F Ratio \\
\hline Linear & 999.9 & 305.1 \\
Quadratic & 248.0 & 75.7 \\
\hline
\end{tabular}

Figure 5-2 shows the response of shoots from a selected line compared with a control line. A significant portion of variability observed in the experiment was attributable to effects of the origin of the primary explant. A set of comparisons between control shoots and those which arose on glyphosate-resistant callus were constructed. These contrasts indicated that only three of the original shoots, from selected calli, produced significantly more microshoots on glyphosateenriched media, than shoots produced from non-selected tissue. The mean numbers of shoots produced from explants of the various lines are presented in Table 57 and indicate that shoots from lines B111, B113, and Al13 retained some degree of glyphosate resistance compared with shoots from non-selected callus.

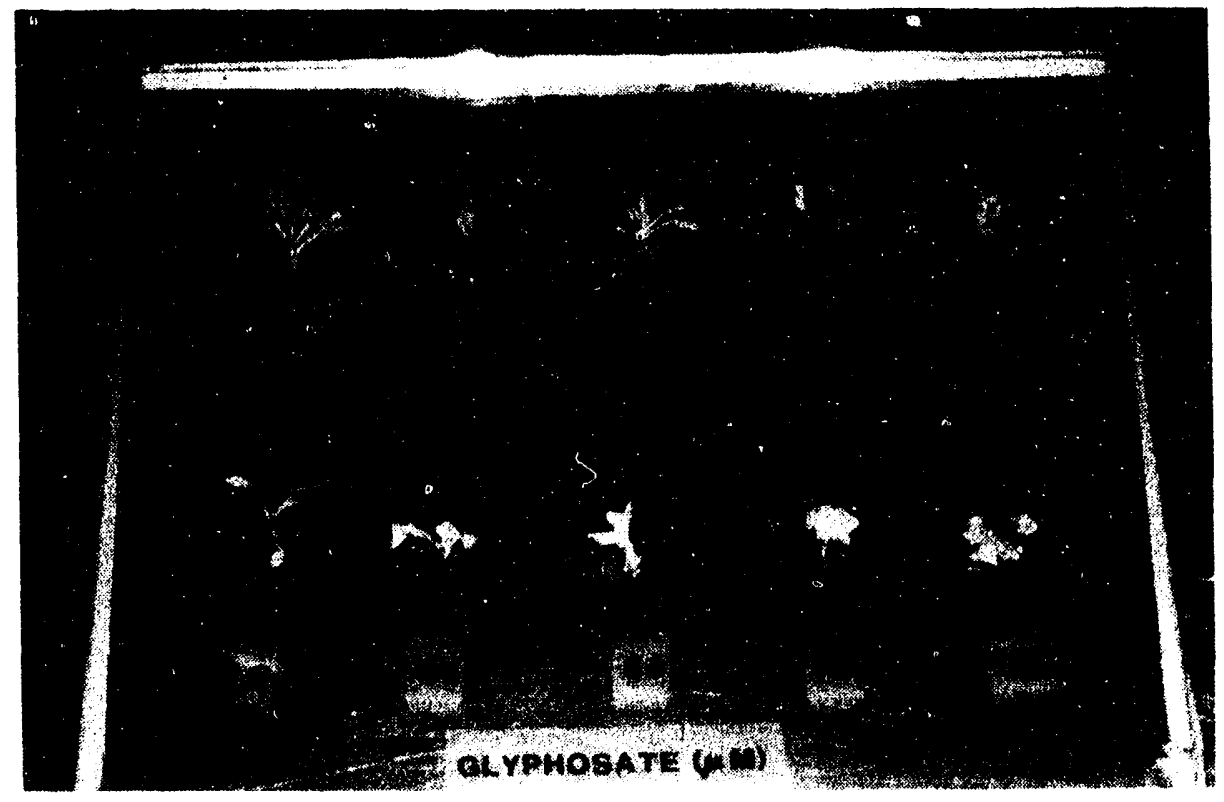

Figure 5-2. Effects of glyphosate in the culture medium on growth of shoots regenerated from resistant and susceptible callus 
Table 5-7

EFFECT OF ORIGIN OF PRIMARY SHOOT (HERBICIDE TOLERANT OR CONTROL, NON-SELECTED, CALLUS TISSUE) ON MULTIPLICATION OF POPLAR SHOOTS AFTER SIX WEEKS CULTURE ON MEDIA AMENDED WITH VARIOUS CONCENTRATIONS OF GLYPHOSATE

Callus Origin of Primary Shoot Mean Number of Shoots ${ }^{a /}$

Non-selected callus

Tolerant callus BIll

Tolerant callus B113

Tolerant callus A113

Tolerant callus A112

Tolerant callus B119

Tolerant callus A114

Tolerant callus B116
1.5

2.7

3.0

2.5

1.9

1.7

2.1

1.6

a/ Mean numbers of shoots per explant averaged over glyphosate concentrations and replications.

The effects of glyphosate treatments were independent of the callus-origin of the primary explant. Mean shoot numbers summarized in Table 5-8 show that increasing concentrations of glyphosate inhibited multiplication of shoots regenerated from both resistant and susceptible callus. 
Table 5-8

EFFECTS OF GLYPHOSATE CONCENTRATION ON NUMBER OF SHOOTS PRODUCED FROM A SINGLE PRIMARY SHOOT AFTER SIX WEEKS OF CULTURE ON MEDIA SUPPLEMENTED WITH VARIOUS CONCENTRATIONS OF HERBICIDE.

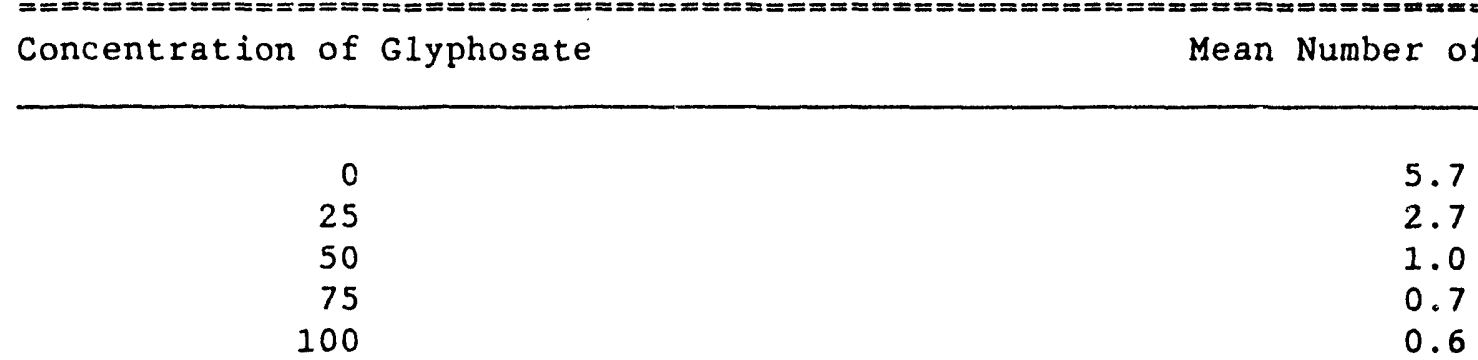

a/Mean numbers of shoots per explant averaged over lines and replications.

The shoots, which regenerated from glyphosate-resistant callus, were transferred to root-inducing medium prior to transfer to greenhouse conditions. After a period of acclimatization, plantlets were allowed to grow to produce enough material for whole-plant evaluation of herbicide tolerance. Plants resulted from 11 of the 18 original callus lines which were selected as glyphosate resistant (Table 5-9). Plantlets produced from NM2 non-seleted callus were included as controls. Cuttings were removed from the plants after about four months in the gretnhouse. These cuttings were rooted and plants were allowed to become established. After three months, samples of plants representing each line of glyphosate-resistant callus were taken for treatment with herbicide. 
Table 5-9

INVENTORY OF POPULUS SHOOTS REGENERATED FROM CALLUS TISSUE PRODUCED ON MEDIA CONTAINING 100 MICROMOLAR GLYPHOSATE

\begin{tabular}{|c|c|c|c|}
\hline Clone & Callus Line & Number of Shoots & Number of Plants \\
\hline NM2 & A111 & 18 & 19 \\
\hline NM2 & A112 & 9 & \\
\hline NM2 & Al13 & 2 & \\
\hline NM2 & A114 & 24 & \\
\hline NM2 & B110 & 3 & 6 \\
\hline NM2 & B111 & 5 & 10 \\
\hline NM2 & B 112 & 60 & 12 \\
\hline NM2 & B113 & 24 & \\
\hline NM2 & B114 & 125 & 45 \\
\hline NM2 & B115 & 10 & \\
\hline NM2 & B116 & 58 & 46 \\
\hline NM2 & $\mathrm{B} 117$ & 13 & 2 \\
\hline NM2 & B118 & 160 & 36 \\
\hline NM2 & B119 & 56 & 20 \\
\hline DN66 & B121 & 3 & \\
\hline DN66 & B122 & 11 & 3 \\
\hline DN66 & B123 & 12 & \\
\hline DN66 & B124 & 7 & \\
\hline DN66 & B125 & 85 & 17 \\
\hline TOTAL & & 629 & 216 \\
\hline
\end{tabular}

Samples of plants from each of 11 lines and non-selected control plants were treated with a spray application of glyphosate at each of the following concentrations: $0,200,2000$, and 20,000 micromolar. After 10 days the plants were evaluated for the effects of glyphosate. All plants that received the highest concentration of herbicide were defoliated, blackened and appeared extremely distressed. A majority of plants were dead. The plants that received the lowest concentration of herbicide (200 micromolar) were unaffected by the treatment. Plants exposed to the intermediate concentration of glyphosate occassionally exhibited necrotic spots on the leaves but were not significantly distressed by the herbicide application. The nonselected control plants behaved in a similar manner to the treated plants. 
Experimental creation of glyphosate-resistant Populus clones has generated some interesting results. Samples of calli that were originally produced in the presence of 300 micromoles of gbyphosate have consistently failed to produce shoots when transferred to media known to promote adventitious shoot production. Samples of glyphosate-resistant calli formed in the presence of 100 micromoles did regenerate shoots when transferred to appropriate medium. Thus, the conditions from which calli were selected exerted a strong influence on the subsequent morphogenic potential of the callus. This observation suggests that the ability to tolerate higher concentrations of herbicide involves changes in the same mechanisms that control cellular differentiation.

When shoots developed from glyphosate-resistant callus were multiplied on media containing no herbicide, some of the shoots reverted to the susceptible phenotype whereas others remained resistant to the herbicide. The loss of resistance after removal of selective pressure indicates that the original resistance was an unstable epigenetic change that was maintained only in the presence of the herbicide. Those shoots that exhibited increased glyphosate tolerance can be assumed to be stable variants produced by of selective pressure.

The growth of shoots and plantlets selected as glyphosate-resistant was observed to be considerably slower than that of non-selected shoots or plantlets. This observation indicates that the development of glyphosate resistance is not a simple independent trait but is rather a complex trait with effects that are manifest on the plant phenotype as a whole. The effect observed is an undesirable reduction in growth that may seriously restrict the use of the primary objective of the 
selection; i.e., glyphosate-resistant Populus clones.

Plants that regenerated from glyphosate-resistant callus may appear to have more tolerance to sprcy application of glyphosate herbicide, particularly the DN66selected clone B125. A DN66 control was not included in the evaluation; therefore, the observed level of tolerance, although it appears significantly higher than the original level observed in an earlier screening, is not conclusively demonstrated. The NM2-selected material does not seem to possess more tolerance over control plants. The concentrations of glyphosate applied in the evaluation $0.2,2.0$, and $20 \mathrm{mM}$ overlap the recommended application rates of the herbicide. Concentrations between 2 and $25 \mathrm{mM}$ are recommended for annual weeds and concentrations between 13 and $50 \mathrm{mM}$ are recommended for perennial weeds. Poplars are killed by $20 \mathrm{mM}$ of glyphosate. It must be concluded that practical tolerance to normal applications of the herbicide glyphosate was not achieved as a result of in vitro selection of glyphosate-tolerant callus tissue. 
Section 6

GENETIC TRANSFORMATION USING AGROBACTERIUM TUMEFASCIENS

A most exciting methodology for improving the genotype of silviculturally important plant species uses genetic engineering to introduce novel genes into plants. Specific genes have been cloned that confer traits such as insect resistance, herbicide tolerance, viral resistance and increased protein content. Such genetic engineering of single genes can complement a traditional breeding program or a somaclonal variation program in which multigenic traits, such as high biomass production, have been maximized. When this work was initiated there were no published reports of the application of genetic engineering technology in forest tree species. However, during the course of this project, an article was published describing the expression of "new" genes in transformed tissue of poplar (Fillati et. a1. 1987).

Genetic engineering (transformation) in plants is typically accomplished by insertion of a fragment of DNA containing the gene(s) of interest into a specific strain of a bacterium, Agrobacterium tumefasciens or Agrobacterium rhizogenes(An et. al., 1985; DeBlock et. al., 1984). The engineered bacterial strain is then used to infect host plant cells, and thereby shuttles the desired DNA sequence into the plant genome. The bacterial strain also contains a gene conferring a selectable marker (typically an antibiotic resistance) that is inserted into the host plant and enables transformed cells to be selected from a mixed population of cells (An et. al., 1985). Plant tissue is placed on a medium enriched with antibiotic and only those cells that are transformed (i.e., whose genome contains the gene(s) donated by the bacterial strain) survive. Survivors are then 
regenerated into whole plants (DeBlock et. al., 1984). The steps involved in genetic engineering of poplars are shown in Figure $\bar{b}-1$.

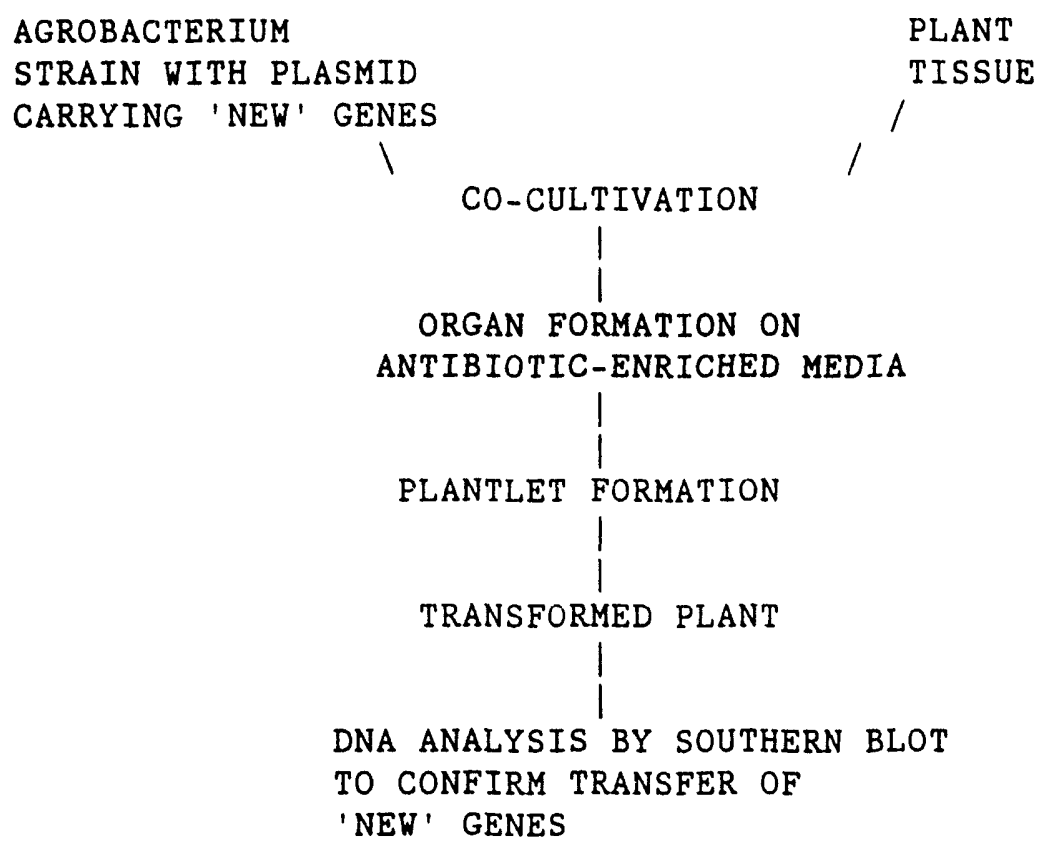

Figure 6-1. General Protocol for Genetic Engineering of Poplar

\section{SENSITIVITY TO THE SELECTABLE MARKER KANAMYCIN}

In order to develop a generally applicable transformation system for Populus, genes were transfered that confer resistance to the antibiotic, kanamycin, since this trait can be used as a selectable marker. For optimal selection of transformed tissues, the kanamycin concentration that inhibits $80-100$ percent of shoot regeneration in non-transformed tissues should be used. Thus, experiments were conducted to determine the sensitivities of in vitro cultured poplar stem segments to the antibiotic, kanamycin. Disinfested stem segments were placed on shoot regeneration medium containing $0,100,300,1000$, and $3000 \mathrm{mg}$ per liter kanamycin. Ten replicate segments were cultured in each treatment. Medium

$$
6-2
$$


containing $300 \mathrm{mg}$ per liter kanamycin inhibited shoot production by 89-96 percent

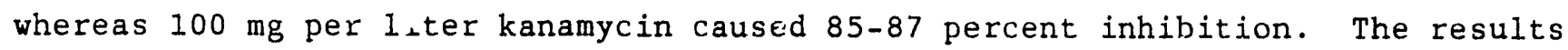
showed that stem segments were sensitive to and affected by kanamycin. Concentrations of 100 and $300 \mathrm{mg}$ per liter antibiotic were established as optimal levels for selection in subsequent transformation experiments.

To determine the effects of kanamycin on multiplication in shoot-tip cultures. microshoots were placed in jars containing multiplication medium supplemented with either 0,100 or $300 \mathrm{mg}$ per liter kanamycin. Five replicates, each containing three explants, were used for each treatment. Multiplication was assessed and compared to controls after 30 days of culture.

The cultures were transferred to sinilar media and maintained for a further 30day period after which similar data were collected. Results are presented in Table 6-1, and show that multiplication was inhibited by the presence of $100 \mathrm{mg} / \mathrm{L}$ kanamycin. Thus, multiplication of shoots on kanamycin-enriched medium can provide additional preliminary evidence for genetic transformation.

Table 6-1

EFFECT OF KANAMYCIN ON MULTIPLICATION IN CULTURES OF NM6 SHOOTTIPS

CULTURES WERE MAINTAINED ON A 30-DAY CYCLE

\begin{tabular}{ccc}
\hline $\begin{array}{l}\text { Concentration of } \\
\text { Kanamycin mg } \backslash 1 .\end{array}$ & $1^{\text {St }} \begin{array}{c}\text { Multiplication Rate } \\
2^{\text {nd }} \text { Cycle }\end{array}$ \\
\hline 0 & 2.1 & 3.8 \\
100 & 1.5 & 1.1 \\
300 & 1.0 & 1.0 \\
500 & 1.0 & 1.0 \\
1000 & 0.9 & 1.0 \\
\hline
\end{tabular}


SELECTION OF INFECTIVE A.TUMEFASCIENS STRAINS

For effective gene transfer by $\underline{A}$. tumefaciens, the vector strain must have a host range which includes the plant to be genetically engineered. Therefore experiments were conducted to determine the strains of A. tumefasciens, that infected the clones collected. Ten strains of the bacterium were tested by co-culture with microshoots. Auxin-independent callus formation in stem segments that were exposed to the bacteria was used as the assessment criterion of an infective strain. Infection occurred with the following strains: A136 pTi octopine strain; A281 pTi 542; A208 pTi T37, ard A281 pTi B0542.

\section{TRANSFORMATION OF POPLAR}

Transformation was achieved by immersion of stem segments in a suspension of actively growing bacteria prior to cultuze on shoot regeneration medium. After three-five days the segments were transferred to similar medium containing both kanamycin, a selective agent, and cephalotoxime, a bacteriocide. In a series of experiments, several factors, including concentration of bacterial suspension, duration of incubation with stem segment, and particular strain of Agrobacterium were assessed in order to optimize the transformation process Table 6-. Shoots or callus which survived and grew on kanamycin-enriched media were assummed to be putative transformants. Figure 6-2 shows the callus production from transformed tissue and the lack of callus formation on the non-transformed tissue. 
Table 6-2

Inventory of Poplar Samples for Which Genetic Transformation Was Confirmed by Southern Blot Analys is

\begin{tabular}{|c|c|c|c|}
\hline Code & Clone & Agrobacterium strain & Number of Shoots \\
\hline B12 & NM 6 & GV3850 \#1 pGA472 & 8 \\
\hline B15 & NM6 & GV3850 \#1 pGA472 & 15 \\
\hline B16 & NM6 & GV3850 \#1 pGA472 & 10 \\
\hline B 22 & NM6 & GV3850 \#1 pGA472 & 20 \\
\hline B24 & NM6 & GV3850 \#1 pGA472 & 4 \\
\hline B25 & NM6 & GV3850 \#1 pGA472 & 14 \\
\hline B27 & NM6 & GV3850 \#1 pGA472 & 10 \\
\hline B 28 & NM6 & GV3850 \#1 pGA472 & 4 \\
\hline B211 & NM 6 & GV3850 \#1 pGA472 & 15 \\
\hline B212 & NM6 & GV3850 \#1 pGA472 & 8 \\
\hline $\mathrm{C} 27$ & NM6 & GV3850 \#3 pGA472 & 10 \\
\hline $\mathrm{C} 28$ & NM6 & GV3850 \#3 pGA472 & 4 \\
\hline $\mathrm{C} 29$ & NM6 & GV3850 \#3 pGA472 & 15 \\
\hline $\mathrm{C} 211$ & NM6 & GV3850 \#3 pGA472 & 25 \\
\hline $\mathrm{C} 212$ & NM 6 & GV3850 \#3 pGA472 & 10 \\
\hline $\mathrm{C} 214$ & NM 6 & GV3850 \#3 pGA472 & 20 \\
\hline $\mathrm{AAO1}$ & NM6 & A281 & 8 \\
\hline $\mathrm{ABO} 1$ & NM6 & A348 pTiA6C35+ & 8 \\
\hline $\mathrm{ABO} 2$ & NM6 & A348 pTiA6C35+ & 10 \\
\hline $\mathrm{ACO} 1$ & NM6 & A348 pTiA6C19+ & 10 \\
\hline $\mathrm{AC} 02$ & NM6 & A348 pTiA6C19+ & 4 \\
\hline $\mathrm{ACO} 3$ & NM6 & A348 pTiA6C19+ & 8 \\
\hline $\mathrm{ACO} 4$ & NM6 & A348 pTiA6C19+ & 8 \\
\hline $\mathrm{BBO} 3$ & NM6 & GV3850 \#3 pGA472 & 10 \\
\hline $\operatorname{CCO} 1$ & NM6 & A348 pTiA6C35t & 8 \\
\hline $\mathrm{CCO} 2$ & NM6 & A348 pTiA6C35t & 4 \\
\hline $\operatorname{Cc} 22$ & NM6 & A348 pTiA6C35t & 4 \\
\hline $\operatorname{Cc} 23$ & NM6 & A348 pTiA6C35+ & 10 \\
\hline $\mathrm{CC} 24$ & NM6 & A348 pTiA6C $35+$ & 12 \\
\hline CD21 & NM6 & GV3850 \#3 pGA472 & 8 \\
\hline
\end{tabular}




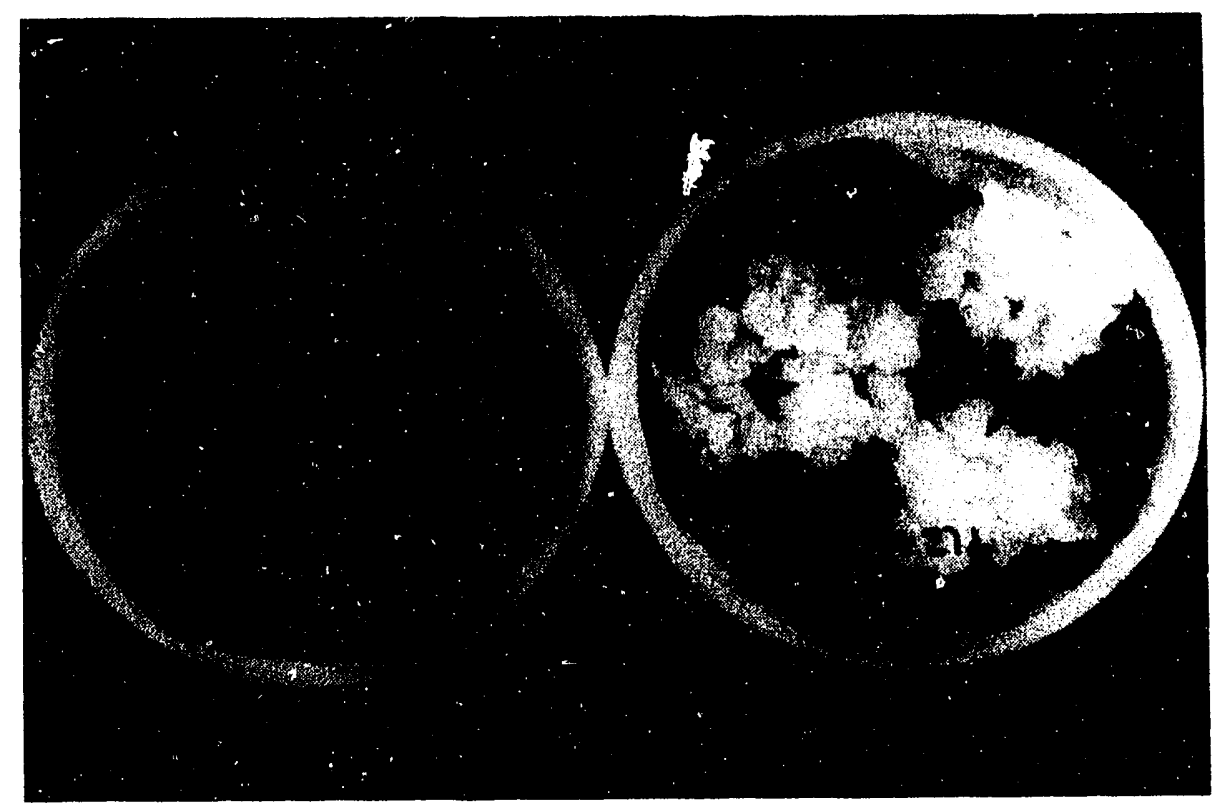

Figure 6-2. Effect of Genetic Transformation on Callus Tissue Growth from Poplar Stem Segments Cultured In Vitro in the Presence of Kanamycin

Shoots that were produced in transformation experiments were assigned a label and transferred to multiplication medium for cloning. A complete list of transformed plant material is in Table $6-2$.

\section{CONFIRMATION OF GENE TRANSFER}

The identity of some of these putative transformants was confirmed by examination of the plant DNA for the presence of a foreign gene (Southern blot analysis). Samples of tissue ( $2 \mathrm{~g}$ fresh weight) from transformed and control plants were frozen in liquid nitrogen, lyophilized, and DNA was extracted using a modification of plant DNA minipreparation method originally obtained from S. Dellaporta (personal communication, E.S.W.). DNA was cleaved into fragments by the enzyme HinD III, and analyzed by Southern Blot analysis on nitrocellulose paper using radiolabeled plasmid GA472 as a probe. Analysis of the callus clones selected as resistant to $6-6$ 
kanamycin, indicated that over 80 percent of these clones contained DNA from the Agrobacterium plasmid in their genomic DNA. Thus, successful transformation of Populus tissue was confirmed.

When such putatively transformed shoots had achieved an appropriate quantity of biomass, a sample of tissue was removed for Southern Blot analysis to confirm the presence of foreign genes. The procedure of Dellaporta et. al.(1983) was used to prepare plant DNA. The DNA samples were digested with restriction enzyme HinD III and subsequently analyzed using procedures described by Fillatti et. al. (1987). An $\mathrm{X}$-ray photograph from electrophoresis gels after hybridization with radioactive DNA probes is presented in Figure 6-3. In the figure, lanes labelled Pop. Cal. none and Pop. Sh. none, represent DNA digests from control callus tissue and shoots that were not previously exposed to $\underline{A}$. tumefasciens. The occurrence of dark bands in the majority of the populus digests that correspond to some of those in the series of dilutions of the standard digest, indicates that plasmid DNA was incorporated into the populus genome and that genetic transformation occurred. 


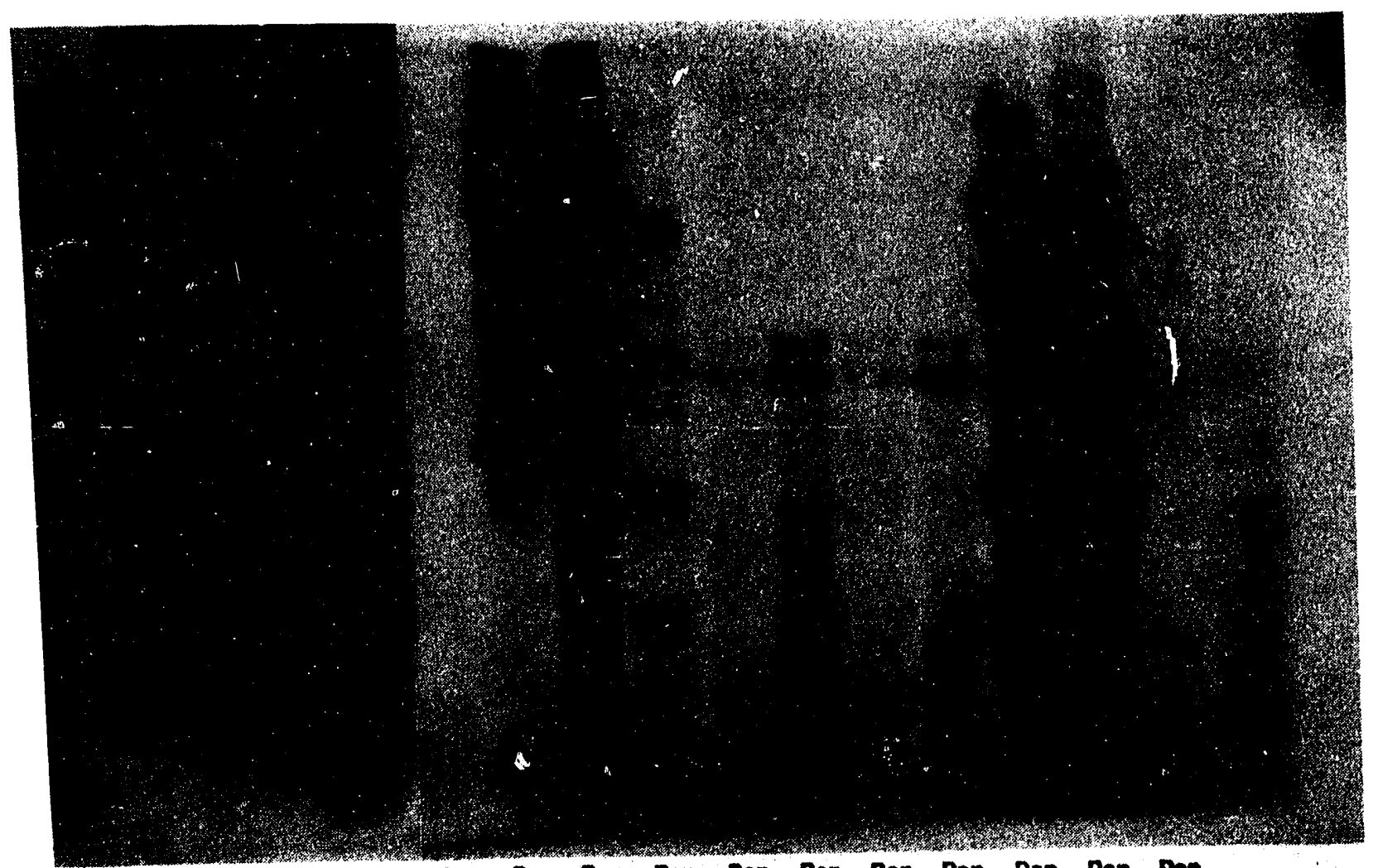

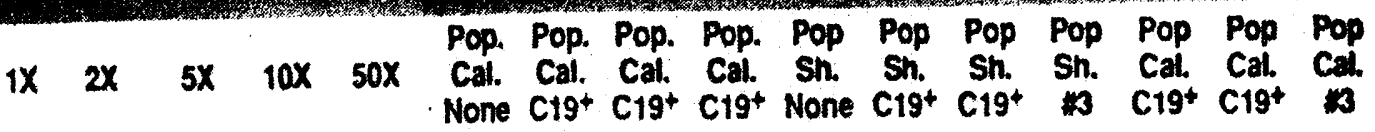

Figure 6-3. Southern Blot of Digested DNA from Control and Transformed Poplar Probed with Radiolabeled DNA from Plasmid PTiA6C19+. Fragments of Foreign DNA Inserted into Poplar Appear as Dark Bands, Some Corresponding to Plasmid Fragments. Lanes with no Dark Bands Represent Digests From Control Plants 
DEVELOPMENT OF IMPROVED STRAINS OF A. TUMEFASCIENS FOR GENETIC ENGINEERING T-DNA
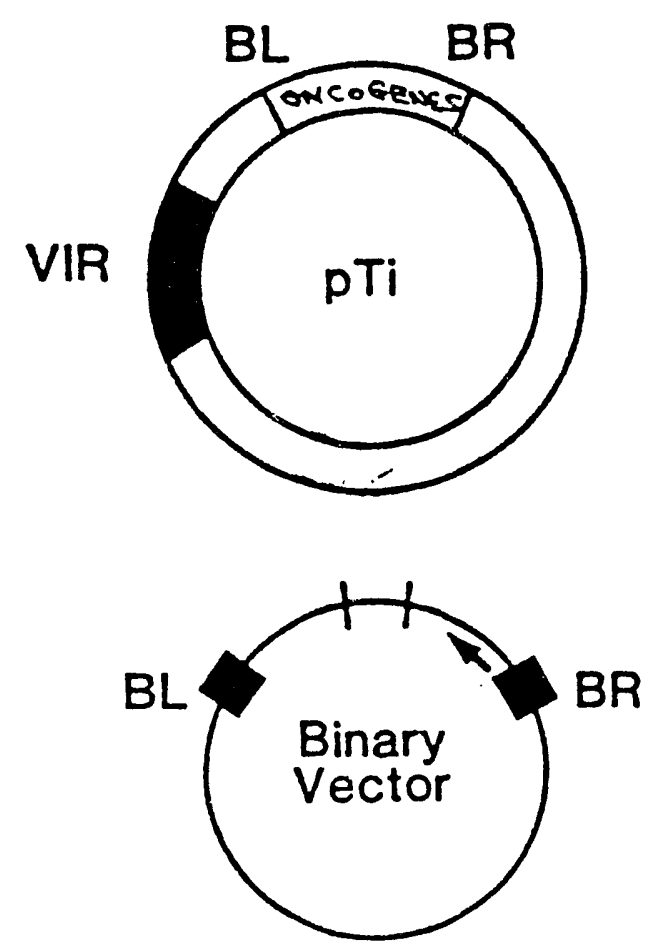

Figure 6-4. Representation of wild-type (upper) and binary vector (lower) plasmids of $\underline{A}$. Tumefisciens

The two plasmids (self-replicating, circular strands of DNA) in the bacterial strains are shown in Figure 6-4. The transfer DNA is located between the left (BL) and right (BR) border regions. These fragments of DNA can be incorporated into the host plant genome. The portion of DNA labelled "vir" in Figure 6-4 is necessary to promote infection but is not transferred 
Transformation was observed at fairly high efficiency: however, the strains of Agrobacterium contained an "armed" wild-type Ti plasmid (i.e., a plasmid carrying "oncogenes" which code for enzymes that produce plant hormones) as well as the mini-binary vector plasmid GA472. This vector system has worked well for producing transgenic plants in Nicotiana, Brassica, and Petunia species. However, it was not efficient in obtaining transgenic poplar plants because of the high frequency of co-transformation with transfer DNA from the wild-type Ti plasmid. This phenomenon of co-transformation occurred frequently following infection of poplar with Agrobacterium in all of the experimental conditions that were used. Since che oncogenes (tumor-inducing genes) were transferred as well as the genes for antibiotic resistance, the transformed cells produced hormone-autonomous callus, from which plants were difficult to regenerate. While some plants have been obtained, a more efficient method to obtain transgenic plants may use the binary vector Agrobacterium strains containing "disarmed" Ti plasmids with deleted or mutated oncogenes. Two "disarmed" strains were obtained but these strains did not contain the mini-Ti plasmid with genes for kanamycin resistance. Therefore, triparental mating techniques were used to insert the mini-Ti plasmid into the disarmed Agrobacterium strains. 


\section{IMPROVEMENT OF TRANSFORMATION SUCCESS}

Using the basic protocol for transformation developed during the first year, several studies were initiated to determine the experimental variables that exerted the greatest influence on the frequency with which transformed shoots were produced. To determine the effects of Agrobacterium strain and kanamycin concentration in the regeneration medium, two strains of bacteria were cocultivated with stem segments of clone DN66 which were then transferred to medic containing 0,100 , or $300 \mathrm{mg} / 1$ kanamycin. The results of the experiment are presented in Table 6-3.

Table 6-3

\section{EFFECT OF AGROBACTERIUM STRAIN AND KANAMYCIN CONCENTRATION ON SHOOT PRODUCTION FROM STEM EXPLANTS OF DN66}

\begin{tabular}{|c|c|c|c|}
\hline \multirow{3}{*}{$\begin{array}{c}\text { Conc. of Kanamycin } \\
\mathrm{mg} \backslash 1\end{array}$} & \multicolumn{3}{|c|}{ Mean Number of Shoots ${ }^{a /}$} \\
\hline & \multicolumn{3}{|c|}{ Agrobacterium Strain } \\
\hline & None & C & $\mathrm{X}$ \\
\hline 0 & $4.0 \mathrm{a}$ & 6.31 & $8.1 \mathrm{C}$ \\
\hline 100 & 1.0 & 1.0 & 1.0 \\
\hline 300 & 0.0 & 0.0 & 0.0 \\
\hline
\end{tabular}

a/Means calculated from 25 replications; those within rows followed by different letters are significantly different at $p=0.05$ by Duncan's New Multiple Range Test.

According to these results, the effects of bacterial strain are mediated by the concentration of kanamycin in the regeneration medium since a strain effect was apparent only when shoots regenerated on media containing no kanamycin. Kanamycin concentration inhibited the regeneration of shoots and completely prevented regeneration at $300 \mathrm{mg} / 1$. 
In a second experiment, the influence of concentration of inoculum three bacterial strains was determined by co-cultivation of stem segments of clones DN66 and NM6 followed by transfer to regeneration medium containing either 0 or $100 \mathrm{mg} / 1$ kanamycin. The results summarized in Table 6-4 show that effects of strain and inoculum concentration were detectable only in the absence of the antibiotic.

Table 6-4

EFFECT OF AGROBACTERIUM STRAIN, CONCENTRATION AND KANAMYCIN IN THE CULTURE MEDIUM ON MEAN NUMBER OF SHOOTS PRODUCED FROM STEM SEGMENTS OF NM6 AND DNǴ POPLARS

Mean Number of Shoots ${ }^{a /}$

Agrobacterium Strain
Inoculum Concn. ce $11 \mathrm{~s} \backslash \mathrm{m} 1 \times 10^{8}$ Kanamycin Concn. 0

$\begin{array}{lllll}\text { None } & & 8.6 \mathrm{c} & 0.6 \mathrm{a} \\ \mathrm{C} & 0.5 & 4.1 \mathrm{a} & 0.9 \mathrm{a} \\ & 0.25 & 9.0 \mathrm{c} & 1.3 \mathrm{a} \\ \mathrm{S} & 0.3 & 5.3 \mathrm{a} & 1.5 \mathrm{a} \\ & 0.15 & 4.3 \mathrm{a} & 1.3 \mathrm{a} \\ \mathrm{U} & 0.6 & 7.9 \mathrm{bc} & 1.6 \mathrm{a} \\ & 0.3 & 6.0 \mathrm{~b} & 0.7 \mathrm{a}\end{array}$

a/Means calculated frcm 20 replicates; those within columns followed by different letters are significantly different at $p=0.05$ by Duncan's New Multiple Range Test.

Since cultivation in the presence of a selective marker (kanamycin) is necessary to distinguish shoots that regenerate from transformed tissue, apparently bacterial strain and concentration of inoculum did not influence the production of transformed shoots. 
The effect of co-cultivation time on the production of transformed shoots was determined when stem segments of NM6 were inoculated with one of four bacterial strains, co-cultivated for either four or seven days, and transferred to regeneration medium containing either 0 or $100 \mathrm{mg} / 1$ kanamycin. Neither bacterial strain nor length of co-cultivation period influenced the production of transformed shoots on media supplemented with kanamycin (Table 6-5).

Table 6-5

EFFECT OF AGROBACTERIUM STRAIN, CONCENTRATION, CO-CULTIVATION TIME, AND KANAMYCIN IN THE CULTURE MEDIUM ON MEAN NUMBER OF SHOOTS PRODUCED FROM STEM SEGMENTS OF NM6

\begin{tabular}{|c|c|c|c|c|}
\hline \multirow{3}{*}{$\frac{\text { Agrobacterium }}{\text { Strain }}$} & \multirow{3}{*}{$\begin{array}{l}\text { Inoculum Concn. } \\
\text { cells } \backslash \mathrm{m} 1 \times 10^{8}\end{array}$} & \multirow{3}{*}{$\begin{array}{l}\text { Co-culivation } \\
\text { Time in Days }\end{array}$} & \multicolumn{2}{|c|}{ Shoot Number ${ }^{a /}$} \\
\hline & & & \multicolumn{2}{|c|}{$\begin{array}{c}\text { Kanamycin Concn. } \\
\text { mg } \backslash 1\end{array}$} \\
\hline & & & 0 & 100 \\
\hline \multirow[t]{2}{*}{ None } & & 4 & 2.3 & 0.1 \\
\hline & & 7 & 0.9 & 0.1 \\
\hline \multirow[t]{2}{*}{ A } & 0.2 & 4 & 2.4 & 0.0 \\
\hline & & 7 & 0.9 & 0.1 \\
\hline \multirow[t]{2}{*}{ C } & 0.2 & 4 & 1.9 & 0.0 \\
\hline & & 7 & 0.7 & 0.0 \\
\hline \multirow[t]{2}{*}{ S } & 0.3 & 4 & 0.6 & 0.0 \\
\hline & & 7 & 2.2 & 0.1 \\
\hline \multirow[t]{2}{*}{$\mathrm{U}$} & 0.3 & 4 & 0.8 & 0.0 \\
\hline & & 7 & 0.5 & 0.0 \\
\hline
\end{tabular}

a/Means calculated from at least 13 observations per treatment.

Shoot formation in the stem segments occurred at very low frequency on media containing the antibiotic. 
When four strains of bacteria, each applied at two inoculum concentrations were co-cultivated with stem segments of clone DN66 at either 0 or $100 \mathrm{mg} / 1$ kanamycin, production of transformed shoots was not influenced by bacterial strain or concentration of inoculum. The results summarized in Tables 6-6 and 6-7 confirmed that kanamycin concentration in the regeneration medium exerted a strong effect on shoot regeneration and that no effects were attributable to the presence of any strain of $\underline{A}$. tumefasciens.

Table 6-6

EFFECT OF AGROBACTERIUM STRAIN ON MEAN NUMBER OF SHOOTS PRODUCED FROM STEM SEGMENTS OF DN66

Agrobacterium Strain Mean Number of Shoots $\mathrm{s}^{\mathrm{a} / \mathrm{b} /}$

\begin{tabular}{lll}
\hline & & \\
None & $2.9 \mathrm{a}$ \\
A & $2.9 \mathrm{a}$ \\
$\mathrm{C}$ & $3.4 \mathrm{a}$ \\
$\mathrm{S}$ & $3.2 \mathrm{a}$ \\
$\mathrm{U}$ & $4.4 \mathrm{a}$ \\
\hline
\end{tabular}

a/Means calculated from at least four observations per tratment.

b/Means followed by different letters are significantly different at $p=0.05$ by Duncan's New Multiple Range Test.

Additional experiments assessed the effect of a second antibiotic, geneticin, as a selective agent in regeneration medium and the assessed influence of a new medium formulation reported by Filatti et. al. (1987) on regeneration of transformed shoots from Agrobacterium-treated stem segments of DN66 and NM6. However, no shoot regeneration was observed in either experiment; therefore, no measure of the effects of the variables was obtained. 
Table 6-7

EFFECT OF KANAMYCIN IN THE CULTURE MEDIUM ON SHOOT PRODUCTION FROM AGROBACTERIUM-TREATED STEM SEGMENTS OF CLONE DN66

Kanamycin Concn.

0

100
Mean Number of Shoots ${ }^{a /}$

$5.1 \mathrm{~b}$

$1.3 \mathrm{a}$

a/Means calculated from at least 57 observations; those followed by different letters are significantly different at $p=0.05$ by Duncan's New Multiple Range Test.

\section{DISCUSSION AND CONCLUSIONS}

The transformation experiments conducted during the course of this work indicate that overall success in the production of transformed shoots and eventually plants is governed by the selection system choice, in this case the concentration of kanamycin, the clone and particular tissue used for the regeneration of shoots. Other factors, such as particular strain of infective $\underline{A}$. tumefasciens, concentration of inoculum, and length of co-cultivation period, have no significant effect on the production of transformed shoots. Thus, careful selection of tissue from a clone capable of high-frequency adventitious shoot production, appears to be the best route to enslire success in transformation studies. The feasibility of achieving genetic transformation in populus clones which are high biomass producers in the Northeast region, has been very successful. Application of this technology using genes conferring important silvicultural traits is possible and will be achieved when these genes are available for incorporation into Agrobacteria. 
Table 6-8

List of A. Tumefasciens Strains Currently Held by NPI

NPI Code

A
B
C
D
E
F
G
H
I
J
K
L
M
N
O
P
Q
R
S
U
V
W
X

Plasmid

GV3850 1

GV3850 \#2

GV3850 \#3

GV3850 \#4

EHA 101

ACH 5 pTi tch 5

A136 pTi (octopine strain)

A281

A348

A519 pTi (succinamopine strain)

A208 pTi (nopaline)

A277 pTiB6-806

Bo542

A348 pTiA6C19+

A348 pTiA6C19-

A348 pTiA6C35+

A348 pTIA6C35-

A348 pTiA6 \#3

GV385

EHA 101

EHA 101

EHA 101

472
LUXA

LUXB

pGA472
Mini Plasmid

PGA472

PGA472

PGA472

pGA472 
Septoria musiva has been identified as the cause of a leaf spot and canker disease of poplar plantations in temperate humid climates (Krupinsky ar. Johnson 1985). The development of symptoms associated with Septoria diseases is complex but is thought to be mediated in part by toxin(s) produced by the pathogen (King et al 1983). In some plant pathogen interactions, where toxins are produced by a fungus, it has been possible to select tissues and cells in vitro vith altered susceptibilities to toxins or crude, biologically active, culture filtrates (Behnke 1980, Brettel and Thomas 1980, Gengenbach et al 1977, Helgeson and Deverall 1983). In many cases, plants produced from these selected cell.s and tissues have shown greater resistance to the pathogen.

Based on the published information, a general approach to the development of Septoria-resistant poplars was devised and is represented diagrammatically in Figure 7-1. Since the proposed screening procedure depended on biolgical activity in fungal culture filtrates, or preparations therefrom, some preliminary work was necessary to establish that any activity in a crude toxin preparation could be correlated with development of disease symptoms in poplar plants, organs, or tissues. 


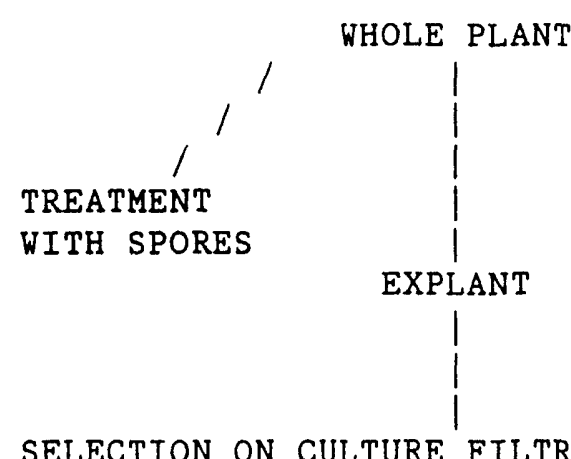

SELECTION ON CULTURE FILTRATE ENRICHED MEDIUM
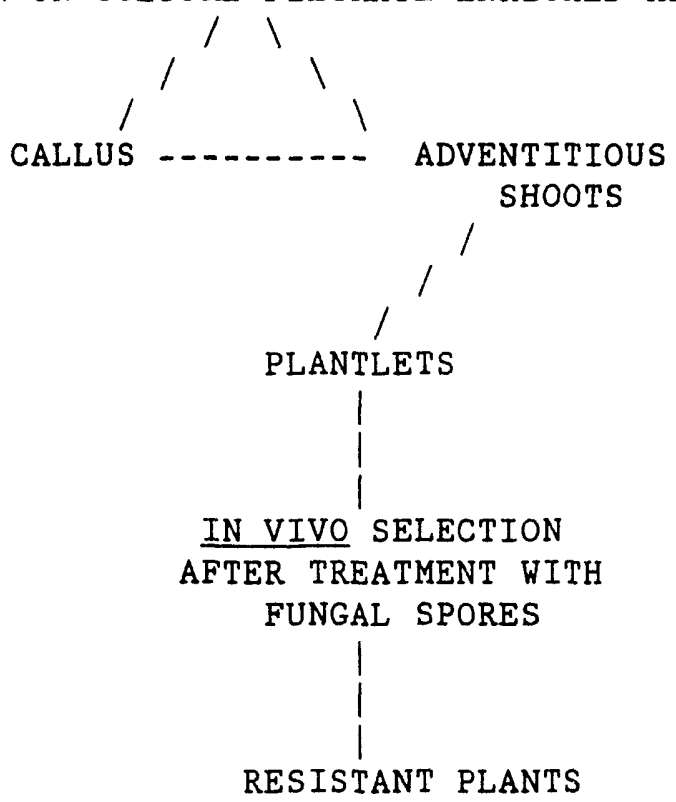

Figure 7-1. Protocol for Selection Against Septoria

WHOLE PLANT INOCULATION

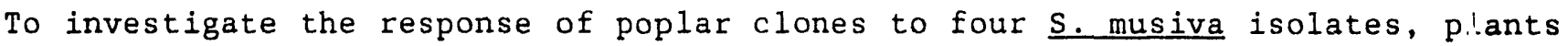
of clones NM2, NM4, NM6, DN10, DN19, DN74, DN134 and JAC4 were sprayed with spore suspensions ( $10^{6}$ spores per $\mathrm{ml}$ ) of four fungal isolates. Water was applied to a set of control plants. Immediately after treatment, plants were covered with plastic bags to provide high humidity conditions conducive to rapid infection. Plastic bags were removed after 72 hours. Plants were examined 10,20 and 30 days after inoculation when the extent of foliar symptom development was scored on a rating scale (Table 7-1). 
Table 7-1

ARBITRARY SCALE FOR THE EVALUATION OF SEPTORIA MUSIVA SYMPTOMS

IN GREENHOUSE PLANTS

Mean Number of Lesions

Category Value

0
$1-4$
$5-12$
$12-24$
$25-50$
$51-100$
$>100$

0

1

2

3

4

$>100$

5

The data were analyzed by analysis of variance. Significant effects of clone, isolate and time were observed as well as significant second-order interactions. The means are presented in Tables $7-2,7-3,7-4$, and $7-5$.

Table 7-2

EFFECT OF FUNGAL ISOLATE ON MEAN CATEGORY VALUE

\begin{tabular}{lc}
\hline Isolate & Mean Value a/ \\
$83-5872$ & $2.2 \mathrm{c}$ \\
$83-5848$ & $3.4 \mathrm{~d}$ \\
$83-5948$ & $1.8 \mathrm{~b}$ \\
$83-5913$ & $2.4 \mathrm{c}$ \\
Water (control) & $0.6 \mathrm{a}$ \\
\hline
\end{tabular}

a/Data were averaged over eight clones and three evaluations; those followed by different letters are significantly different by Duncan's New Multiple Range Test at $\mathrm{p}=0.05$. 
Table 7-3

EFFECT OF CLONE ON THE DEVELOPMENT OF DISEASE SYMPTOMS IN GREENHOUSE GROWN PLANTS. DATA WERE AVERAGED OVER FIVE ISOLATES AND THREE EVALUATION TIMES

\begin{tabular}{ll}
\hline Clone & Mean Value \\
\hline NM2 & $2.9 \mathrm{~d}$ \\
NM4 & $1.4 \mathrm{a}$ \\
NM6 & $2.9 \mathrm{~d}$ \\
DN10 & $2.4 \mathrm{c}$ \\
DN19 & $1.7 \mathrm{ab}$ \\
DN74 & $2.0 \mathrm{~b}$ \\
DN134 & $2.0 \mathrm{~b}$ \\
JAC4 & $1.4 \mathrm{a}$ \\
\hline
\end{tabular}

a/Means followed by different letters are significantly different by Duncan's 'Tew Multiple Range Test at $\mathrm{p}=0.05$.

Table 7-4

EFFECT OF NUMBER OF DAYS POST-INOCULATION ON DEVELOPMENT OF

FOLIAR DISEASE SYMPTOMS IN GREENHOUSE-GROWN POPLARS.

DATA ARE AVERAGE CATEGORY VALUES FROM EIGHT CLONES AND FIVE TREATMENTS.

\begin{tabular}{cc}
\hline Days to Evaluation & Mean Value \\
\hline & \\
10 & $0.7 \mathrm{a}$ \\
20 & $2.2 \mathrm{~b}$ \\
30 & $3.4 \mathrm{c}$ \\
\hline
\end{tabular}

a/Means followed by different letters are significantly different by Duncan's New Multiple Range Test at $p=0.05$. 
Table 7-5

EFFECT OF CLONE AND FUNGAL ISOLATE ON THE SEVERITY OF FOLIAR
SYMPTOMS IN GREENHOUSE-GROWN POPLARS. DATA ARE AVERAGED OVER THREE EVALUATIONS.

Mean Foliar Rating ${ }^{a /}$

S. Musiva Isolate

\begin{tabular}{llllll}
\hline Clone & $83-5872$ & $83-5848$ & $83-5948$ & $83-5913$ & Water \\
\hline NM2 & $3.8 \mathrm{~cd}$ & $3.8 \mathrm{bc}$ & $1.3 \mathrm{a}$ & $4.3 \mathrm{c}$ & $1.1 \mathrm{a}$ \\
NM4 & $0.6 \mathrm{a}$ & $3.5 \mathrm{bc}$ & $1.6 \mathrm{a}$ & $0.8 \mathrm{a}$ & $0.4 \mathrm{a}$ \\
NM6 & $4.1 \mathrm{~d}$ & $4.3 \mathrm{c}$ & $1.6 \mathrm{a}$ & $3.8 \mathrm{c}$ & $0.5 \mathrm{a}$ \\
DN10 & $3.0 \mathrm{c}$ & $4.3 \mathrm{c}$ & $2.5 \mathrm{~b}$ & $1.8 \mathrm{~b}$ & $0.8 \mathrm{a}$ \\
DN19 & $0.5 \mathrm{a}$ & $2.5 \mathrm{a}$ & $1.8 \mathrm{ab}$ & $3.5 \mathrm{c}$ & $0.3 \mathrm{a}$ \\
DN74 & $1.5 \mathrm{~b}$ & $3.3 \mathrm{ab}$ & $2.0 \mathrm{ab}$ & $2.3 \mathrm{~b}$ & $1.1 \mathrm{a}$ \\
DN134 & $2.6 \mathrm{c}$ & $3.0 \mathrm{ab}$ & $1.8 \mathrm{ab}$ & $2.2 \mathrm{~b}$ & $0.5 \mathrm{a}$ \\
JAC4 & $1.3 \mathrm{ab}$ & $2.8 \mathrm{a}$ & $1.7 \mathrm{ab}$ & $0.6 \mathrm{a}$ & $0.3 \mathrm{a}$ \\
\end{tabular}

a/Means within a column followed by a different letter are significantly different by Duncan's New Multiple Range Test at $p=0.05$.

Leaf lesions on four clones are shown in Figure 7-2. In general, the clones could be grouped into three broad categories: i.e., least susceptible (NM4, DN19 and JAC4), intermediate ( DN74 and DN134), and most susceptible (NM2, NM6 and DN10). Isolates could also be grouped: 83-5848 most virulent: 83-5872 and 83-5913 intermediate, and 83-5948 least virulent. Disease symptoms generally increased in severity with time after inoculation. However, significant interactions pointed to exceptions to these generalities: DN19 appeared particularly susceptible to isolate 83-5913, while clone NM4 appeared resistant to all isolates except 835848 . 


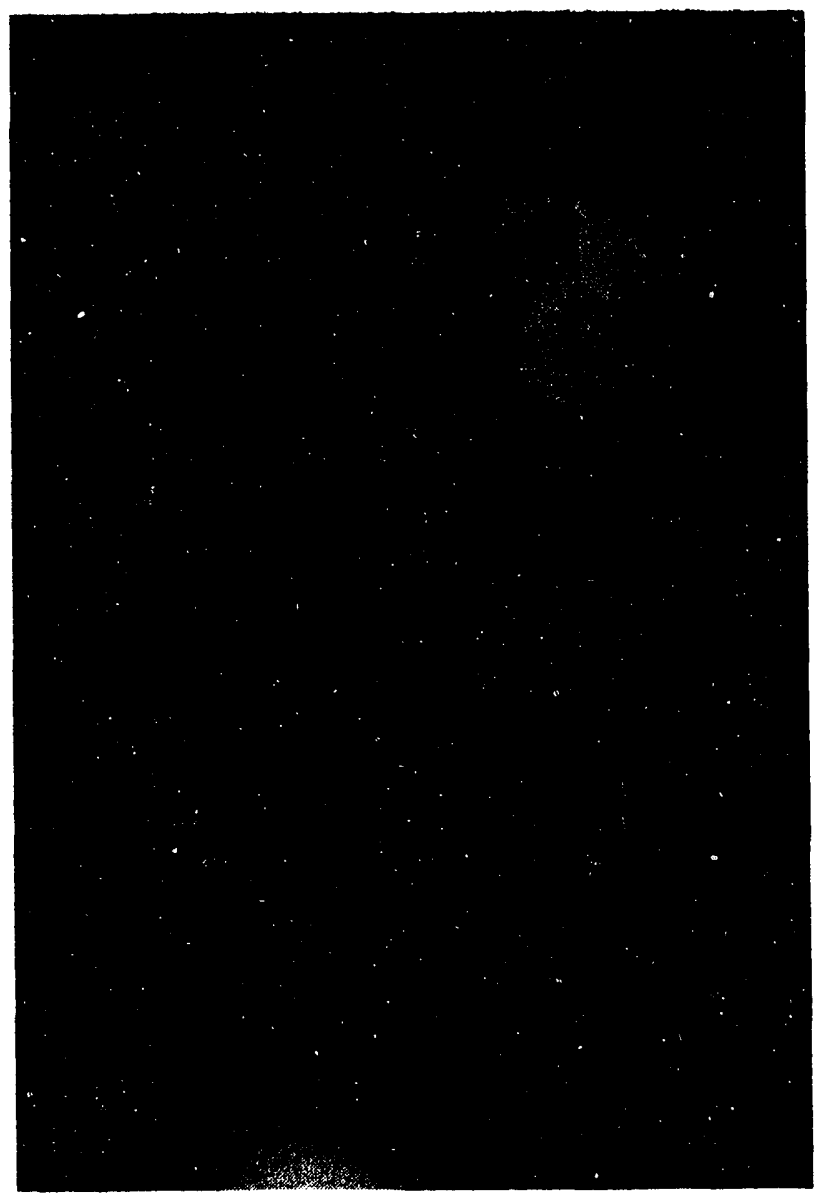

Figure 7-2. Lesions on Leaves from four Poplar Clones after Inoculation with a Spore Suspension of $\underline{\text { S. Musiva }}$

$$
7-6
$$


DETACHED LEAF, STEM AND PETIOLE INOCULATION

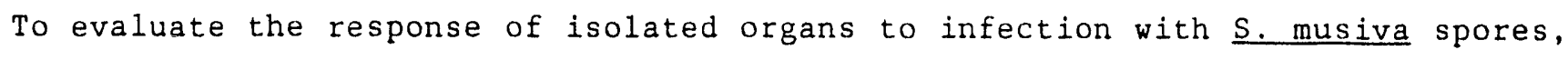
petiole and stem segments (approx. $3 \mathrm{~cm}$ long) from clones NM2, NM4, NM6, DN10, DN19, DN74, DN134 and JAC4 were placed on water agar. One 10-microliter droplet of a spore suspension ( $10^{6}$ spore per $\mathrm{ml}$ ) was placed on the center of each segment. Suspensions were prepared from spores of isolates 83-5872 and 83-5913. The presence or absence of lesions was scored 16 days after inoculation. The percentage of segments that developed disease-like lesions are presented in Table 7-6. The data indicate that petiole infection with isolate $83-5872$ produced symptoms that tended to correlate with data from the greenhouse study: however, data from the stem tissue and from isolate 83-5913 showed no correlation with the whole plant study. 
Table $7-6$

EFFECT OF CLONE AND ISOLATE ON PERCENT OF STEM AND PETIOLE SECTIONS THAT EXHIBITED LESIONS 16 DAYS AFTER TREATMENT WITH A SUSPENSION OF S. MUSIVA SPORES

\begin{tabular}{lcrrr}
\hline & \multicolumn{5}{c}{ Fungal } & Isolate & & \\
\hline Clone & Petiole & Stem & Petiole & Stem \\
\hline NM2 & 100 & 0 & 20 & 0 \\
NM4 & 30 & 0 & 0 & 0 \\
NM6 & 50 & 0 & 25 & 0 \\
DN10 & 80 & 30 & 0 & 0 \\
DN19 & 20 & 0 & 0 & 0 \\
DN74 & 40 & 0 & 0 & 0 \\
DN134 & 20 & 0 & 20 & 0 \\
JAC4 & 40 & 80 & 0 & 0 \\
& & & & \\
\hline
\end{tabular}

Leaf discs from the same clones were inoculated with 10 microliters of spore suspensions of all fungal isolates. The effect of leaf age on the development of disease lesions was determined by comparing discs from young leaves (third below apex) and from old leaves (seventh below apex). Results are presented in Tables 7-7 and 7-8 that show leaf age has an influence on the development of lesions, since younger leaves in general seemed more susceptible to infection and colonization than older leaves.

The data also indicated to point to the interactive effects of clone and fungal isolate on the development of disease symptoms. The pathogen-host interaction in this particular system appears to be very complex, since manifestation of symptoms is influenced by genotype of the plant age and developmental stage of the target tissue and by the particular strain of fungus. 
Table 7-7

EFFECT OF CLONE AND ISOLATE ON LESION AREA, MEASURED IN MM², IN DISCS FROM OLDER EXPANDED LEAVES AFTER TREATMENT WITH

S. MUSIVA SPORE SUSPENSIONS

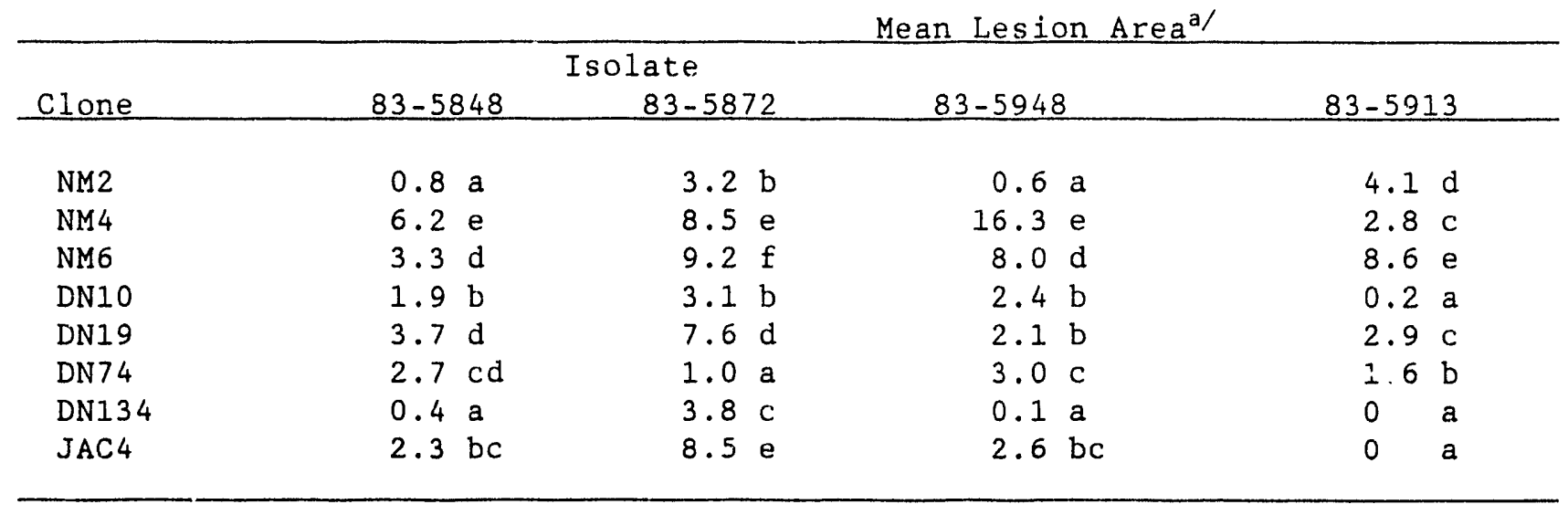

a/Means within a column followed by a different letter are significantly different by Duncan's New Multiple Range Test at $p=0.05$.

Table 7-8

EFFECT OF CLONE AND ISOLATE ON LESION AREA, MEASURED IN MM ${ }^{2}$, IN DISCS FROM YOUNGER EXPANDING LEAVES AFTER TREATMENT WITH S. MUSIVA SPORE SUSPENSIONS

\begin{tabular}{lrrrr}
\hline \multicolumn{5}{c}{ Mean Lesion Area } \\
\hline \multicolumn{7}{c}{ Isolate } \\
Clone & $83-5848$ & $83-5872$ & $83-5948$ & $83-5913$ \\
\hline NM2 & $8.9 \mathrm{abc}$ & $27.6 \mathrm{c}$ & $4.8 \mathrm{a}$ & 0 \\
NM4 & $10.5 \mathrm{abc}$ & $0.7 \mathrm{a}$ & $14.2 \mathrm{ab}$ & 0 \\
NM6 & $4.9 \mathrm{a}$ & $3.4 \mathrm{a}$ & $5.0 \mathrm{a}$ & 0 \\
DN10 & $0.6 \mathrm{a}$ & $1.1 \mathrm{a}$ & $4.9 \mathrm{a}$ & 0 \\
DN19 & $11.0 \mathrm{bc}$ & $33.6 \mathrm{c}$ & $19.5 \mathrm{~b}$ & 0 \\
DN74 & $3.8 \mathrm{ab}$ & $0.2 \mathrm{a}$ & $8.3 \mathrm{a}$ & 0 \\
DN134 & $17.2 \mathrm{c}$ & $9.9 \mathrm{ab}$ & $9.2 \mathrm{a}$ & 0 \\
JAC4 & $7.3 \mathrm{abc}$ & $11.8 \mathrm{~b}$ & $10.5 \mathrm{ab}$ & 0 \\
\hline
\end{tabular}

a/Means within a column followed by a different letter are significantly different. by Duncan's multiple range test at $p=0.05$. 
BIOLOGICAL ACTIVITY OF SEPTORIA CULTURE FILTRATES

Several liquid media were evaluated for in vitro culture of fungal isolate 835848. Three media were compared: a simple V8 medium $\left(200 \mathrm{ml}\right.$ v8 juice and $3 \mathrm{~g} \mathrm{CaCO}_{3}$ per liter); a medium described by Bousquet et. al. 1980 (B), and a medium described by Kent and Strobel 1976 (KS). Aliquots ( $2 \mathrm{ml}$ ) of spore suspension were added to one-liter batches of medium in three-liter flasks that were agitated on a rotary shaker $(95 \mathrm{rpm})$ at $26^{\circ} \mathrm{C}$ under 16 hours of light. Cultures were harvested after three weeks of incubation when the KS medium was observed to have stimulated the best proliferation of fungal mycelium. Preliminary evaluation of crude culture filtrates from the flasks using a leaf disc assay indicated that filtrates from both KS and B media were capable of producing disease-like lesions. Since the KS medium promoted better growth of fungal mycelium this was selected as the medium for further production. A typical example of a septoria liquid culture is presented in Figure $7-3$.

Liquid cultures were harvested by filtration through a coarse-sintered glass funne1. A spore-free filtrate was concentrated 10 -fold by rotary evacuation, lyophilized and dialyzed against cold tap water. The dialysate was lyophilized for storage. Generally, approximately $2 \mathrm{~g}$ of crude extract was obtained from each two liters of culture medium.

Crude extracts were obtained from isolates 83-5913,83-5848 and 83-5872. Samples of two of the extracts were suspended in sterile water and 10 microliter aliquots were applied to leaf discs of clones NM2, NM4, NM6, DN10, DN19, DN74, DN134 and JAC4. Aliquots of spore suspensions were also applied to discs. After 20 days, 
leaf discs were inspected for presence of lesions. The percent ages of discs with lesions are presented in Table 7-9.

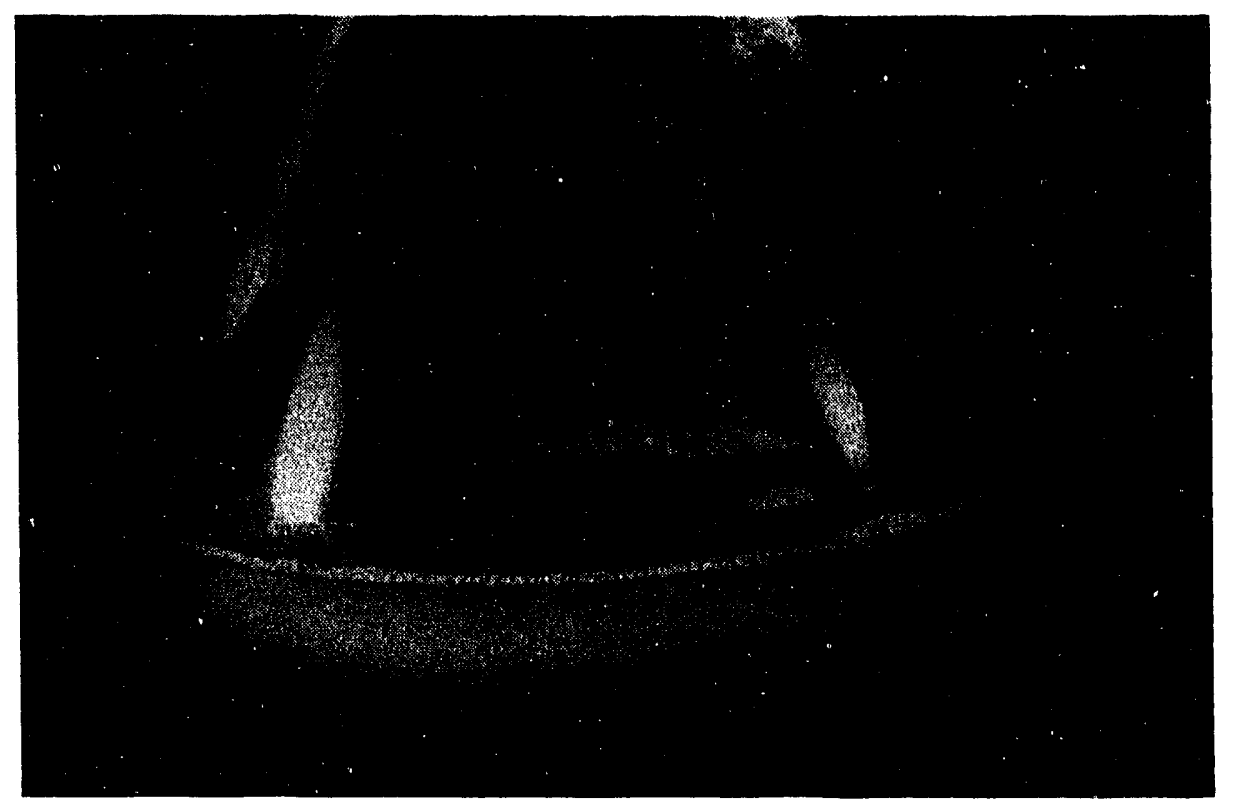

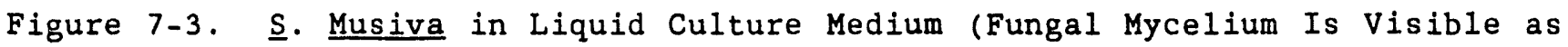
Sediment)

Table 7-9

EFFECT OF FUNGAL CULTURE FILTRATE EXTRACT AND SPORES ON PERCENTAGE OF LEAF DISCS THAT DEVELOPED DISEASE-LIKE LESIONS. DATA WERE TAKEN AFTER 20 DAYS INCUBATION.

Percent Leaf Discs with Lesions

\begin{tabular}{|c|c|c|c|c|}
\hline \multirow[b]{3}{*}{ Clone } & \multicolumn{4}{|c|}{ Isolate Number } \\
\hline & \multicolumn{2}{|c|}{$83-5913$} & \multicolumn{2}{|r|}{$83-5848$} \\
\hline & Spore & Extract & Spore & Extract \\
\hline NM2 & 100 & 100 & 40 & 80 \\
\hline NM4 & 60 & 100 & 100 & 0 \\
\hline NM6 & 100 & 80 & 100 & 60 \\
\hline DN10 & 20 & 100 & 80 & 20 \\
\hline DN19 & 80 & 100 & 100 & 20 \\
\hline DN74 & 40 & 80 & 60 & 20 \\
\hline DN134 & 60 & 100 & 100 & 20 \\
\hline
\end{tabular}


Since culture filtrates were found to possess biological activity, filtrate extracts were applied to in vitro cultures of populus tissues and organs to assess the potential for use of such extracts as screening agents for the identification of materials with enhanced pathogen tolerance or resistance. Extracts were dissolved in 95 percent ethyl alcohol and aliquots of solutions were added to autoclaved media while still hot. These aliquots were added so that alcohol never accounted for more than $10 \mathrm{ml}$ of any liter of medium. Extracts of isolates 835948 and 83-5913 were added to culture medium. Callus tissue $(0.5 \mathrm{~g})$ from clone NM4 stems and leaves was transferred to the enriched medium and reweighed after 16 days of incubation. Data from this study were analyzed. The source of the callus did not exert an effect; however, the presence of fungal-culture filtrate extract from isolate 83-5913 significantly affected callus growth (Table 7-10).

$$
\text { Table } 7-10
$$

EFFECT OF FUNGAL CULTURE FILTRATE EXTRACTS ON FRESH WEIGHT OF CALLUS TISSUE FROM CLONE NM4 AFTER 16 DAYS INCUBATION

(INITIAL EXPLANT WAS $0.5 \mathrm{G}$ )

\begin{tabular}{|c|c|}
\hline Extract Isolate Number & Mean Fresh Weight ${ }^{a /}(g)$ \\
\hline $83-5913(0.5 g \backslash L)$ & $1.7 \mathrm{~b}$ \\
\hline $83-5913(1.0 \mathrm{~g} \backslash \mathrm{L})$ & $1.0 \mathrm{a}$ \\
\hline $83-5848(1.0 \mathrm{~g} \backslash \mathrm{L})$ & $1.5 \mathrm{ab}$ \\
\hline Control & $1.9 \mathrm{~b}$ \\
\hline
\end{tabular}

a/Means followed by different letters are significantly different by Duncan's New Multiple Range Test at $p=0.05$.

Experiments were performed with shoot-tip cultures of clones NM2 and NM6 grown in the presence of fungal extracts when microshoots were transferred to enriched multiplication medium. Development $c$ f disease-like symptoms on cultured

$$
7-12
$$


microshoots was assessed after 21 days incubation. After analyzing the data, no significant differences in necrotic spot development could be ascribed to clone or to the presence of fungal culture filtrates. When attempts were made to repeat these initial observations two problems emerged. The first was associated with a difficulty in maintaining sterility in media supplemented with culture filtrates; and second, the addition of ethyl alcohol to culture media exerted a negative effect on control cultures. A different method of sterilization was investigated for the culture filtrate extracts. Arrangements were made with a local hospital to expose samples of extracts to ethylene oxide gas at $27^{\circ} \mathrm{C}$ for four hours. These sterile samples were incorporated into tissue culture media and effects of the culture filtrates were reassessed. Samples of callus tissue $(0.5 \mathrm{~g})$ from clones NM6 and DN134 were transferred to media containing $0,0.1,0.25$ and $0.5 \mathrm{~g} / \mathrm{L}$ of extracts from three isolates. After four weeks, the callus was reweighed and data were analyzed. Results for the experiment with NM6 are presented in Table 7-11 and for DN134 in Tables 7-12 and 7-13. DN134 callus was affected significantly by both origin of the extract and by concentration in the culture medium, whereas NM6 callus growth was independent of the source of the extract but was influenced significantly by concentration. 
EFFECT OF CONCENTRATION OF FUNGAL CULTURE FILTRATE EXTRACT

ON FRESH WEIGHT OF NM6 STEM CALLUS

\begin{tabular}{cc}
\hline Concentration of Extract $(\mathrm{g} / \mathrm{L})$ & Fresh Weight of Callus $(\mathrm{g})^{\mathrm{a} /}$ \\
$0.0 \mathrm{~g} \backslash \mathrm{L}$ & $1.78 \mathrm{bc}$ \\
$0.1 \mathrm{~g} \backslash \mathrm{L}$ & $1.99 \mathrm{c}$ \\
$0.25 \mathrm{~g} \backslash \mathrm{L}$ & $1.48 \mathrm{ab}$ \\
$0.5 \mathrm{~g} \backslash \mathrm{L}$ & $1.34 \mathrm{a}$ \\
\hline
\end{tabular}

a/Data are means of 15 observations and are pooled over isolates, those followed by different letters are significantly different by Duncan's New Multiple Range Test at $\mathrm{p}=0.05$.

Table 7-12

EFFECT OF ORIGIN OF CULTURE FILTRATE EXTRACTS ON FRESH WEIGHT GAIN OF DN134 STEM CALLUS

\begin{tabular}{cc}
\hline Extract Origin & Fresh Weight of Callus \\
\hline & \\
$83-5848$ & $1.65 \mathrm{~b}$ \\
$83-5872$ & $0.99 \mathrm{a}$ \\
$83-5913$ & $1.11 \mathrm{a}$ \\
Control & $1.60 \mathrm{~b}$ \\
\hline
\end{tabular}

a/Data are means of 15 observations, those followed by different letters are significantly different by Duncan's New Multiple Range Test at $p=0.05$. 
Table 7-13

EFFECT OF CONCENTRATION OF S. MUSIVA CULTURE FILTRATE PREPARATION ON FRESH WEIGHT OF DN134 STEM CALLUS

\begin{tabular}{cc}
\hline Cancentration of Extract $(\mathrm{g} \backslash \mathrm{I})$ & Fresh Weight of Callus $(\mathrm{g})^{\mathrm{a}}$ \\
\hline & \\
0.0 & $1.60 \mathrm{c}$ \\
0.1 & $1.47 \mathrm{c}$ \\
0.25 & $1.24 \mathrm{~b}$ \\
0.5 & $1.03 \mathrm{c}$ \\
\hline
\end{tabular}

a/Data are means of 15 observations, those followed by different letters are significantly different by Duncan's New Multiple Range Test at $p=0.05$.

Thus, the data clearly showed that growth in disorganized poplar tissue cultures was influenced by exposure to an extract from filtered media in which $\underline{s \text {. musiva }}$ was grown.

A further study was initiated to evaluate the effects of liquid, concentrated, spore-free, Septoria culture filtrates on fresh weight gain of callus tissue of clones NM6 and DN134. Isolates of the fungus were cultured in KS medium. Culture filtrate was prepared and concentrated from four liters to $200 \mathrm{mls}$ by rotary evaporation at $26^{\circ} \mathrm{C}$. The concentrate was added to callus maintenance medium at 0 , $0.5,2.5,5.0,12.5,25.0,50.0$, and $100.0 \mathrm{mls}$ per liter of medium prior to sterilization by autoclaving. The concentrations of culture filtrate in the plant culture medium were $0,1,5,10,25,50,100$, or 200 percent of the original in the fungal culture medium. Approximately $0.5 \mathrm{~g}$ of fresh callus tissue was transferred to each aliquot of solid medium and grown for 28 days. Fresh weight of the callus tissue was measured at 14 and 28 days after transfer to the enriched 
medium. Since fresh weight changed little during the first 14 days, the weight gain during the second period was calculated for each callus sample and was summarized by analysis of variance.

Effects of clone, Septoria isolate and concentration were sigrificant. The effects of isolate and concentration were dependent on each other since a signifcant interaction was observed among the factors. Results presented in Tables 7-14, 715, 7-16 and 7-17 show that mean fresh weight gain was greatest in clone NM6 and, in general, addition of between 1 and 10 percent fungal filtrate concentrate was stimulatory whereas 100 percent or more was inhibitory. Isolate 5913-104C at 10 percent level stimulated the greatest fresh weight increase and isolate $5848-104 \mathrm{~A}$ was inhibitory only when present at 200 percent level.

The slight stimulation of growth produced by incorporation of a non-dialysed, fungal, culture-filtrate concentrate into a callus maitenance medium, may be a function of increased availibility of nutrients such as sugars or amino acids. The effect may be due to the production of compounds that in low concentrations are stimulatory to plant growth but are inhibitory at higher concentrations. It is conceivable that the biologically active crude toxin produced by the fungus acts as a stimulant at low concentrations and as an inhibitor at higher concentrations. 
EFFECT OF CLONE ON FRESH WEIGHT GAIN IN POPULUS CALLUS CULTURED IN MEDIA AMENDED WITH LIQUID, FUNGAL, CULTURE FILTRATES FROM SEVERAL SEPTORIA ISOLATES

\begin{tabular}{lc}
\hline Clone & Fresh Weight Gain $(g)^{\mathrm{a} /}$ \\
NM6 & $0.44 \mathrm{~b}$ \\
DN134 & $0.25 \mathrm{a}$ \\
\hline
\end{tabular}

a/Means calculated from 140 observations per clone; those followed by different letters are significantly different at $p=0.05$ by Duncan's New Multiple Range Test.

Table 7-15

EFFECT OF SEPTORIA ISOLATE ON FRESH WEIGHT GAIN IN POPULUS CALLUS CULTURED IN MEDIA AMENDED WITH LIQUID, FUNGAL, CULTURE FILTRATES

\begin{tabular}{lc}
\hline Isolate & Fresh Weight Gain $(\mathrm{g})^{\mathrm{a} /}$ \\
\hline $5848104 \mathrm{~A}$ & $0.39 \mathrm{~b}$ \\
5872 104B & $0.30 \mathrm{a}$ \\
5913 104C & $0.36 \mathrm{ab}$ \\
None & $0.34 \mathrm{ab}$ \\
\hline
\end{tabular}

a/Means calculated from 70 observations; those followed by different letters are significantly different at $p=0.05$ by Duncan's New Multiple Range Test. 
Table 7-16

EFFECT OF DOSE OF LIQUID, FUNGAL, CULTURE FILTRATE ON FRESH WEIGHT GAIN OF POPULUS CALLUS CULTURED IN MEDIA SUPPLEMENTED WITH SUCH FILTRATES PREPARED FROM SEPTORIA MUSIVA CULTURES

\begin{tabular}{cc}
\hline Liquid Filtrate & Fresh Weight Gain $(\mathrm{g})^{\mathrm{a}}$ \\
\hline & \\
1 & $0.34 \mathrm{bc}$ \\
5 & $0.42 \mathrm{~cd}$ \\
10 & $0.46 \mathrm{de}$ \\
25 & $0.54 \mathrm{e}$ \\
50 & $0.31 \mathrm{~b}$ \\
100 & $0.27 \mathrm{~b}$ \\
200 & $0.29 \mathrm{~b}$ \\
& $0.17 \mathrm{a}$ \\
\hline
\end{tabular}

a/Means calculated from at least 14 observations; those followed by different letters are significantly different at $p=0.05$ by Duncan's New Multiple Range Test.

Table 7-17

EFFECT OF SEPTORIA ISOLATE ORIGIN AND DOSE OF LIQUID CULTURE FILTRATE ON FRESH WEIGHT GAIN OF POPULUS CALLUS CULTURED IN VITRO ON MEDIA SUPPLEMENTED WITH FILTRATES

\begin{tabular}{cccc}
\hline \multicolumn{5}{c}{ Mean Fresh Weight Gain $(\mathrm{g})^{\mathrm{a} /}$} \\
\hline \% Liquid Filtrate & $5848104 \mathrm{~A}$ & $\frac{\text { Septoria Isolate }}{5872 ~ 104 \mathrm{~B}}$ & $5913104 \mathrm{C}$ \\
\hline 1 & $0.44 \mathrm{~b}$ & $0.37 \mathrm{cde}$ & $0.45 \mathrm{bc}$ \\
5 & $0.40 \mathrm{~b}$ & $0.46 \mathrm{de}$ & $0.54 \mathrm{~cd}$ \\
10 & $0.48 \mathrm{~b}$ & $0.49 \mathrm{e}$ & $0.71 \mathrm{~d}$ \\
25 & $0.43 \mathrm{~b}$ & $0.20 \mathrm{abc}$ & $0.29 \mathrm{ab}$ \\
50 & $0.43 \mathrm{~b}$ & $0.09 \mathrm{a}$ & $0.28 \mathrm{ab}$ \\
100 & $0.33 \mathrm{ab}$ & $0.29 \mathrm{bcd}$ & $0.26 \mathrm{ab}$ \\
200 & $0.22 \mathrm{a}$ & $0.15 \mathrm{ab}$ & $0.13 \mathrm{a}$ \\
\hline
\end{tabular}

a/Mean values calculated from at least 14 observations; those within columns followed by different letters are significantly different at $p=0.05$ by Duncan's New Multiple Range Test. 
An experiment was initiated to assess the effects of extracts of filtrates of Septoria isolates on fresh weight gain of callus tissue of clones NM6 and DN134. This experiment included a replication of a study detailed in the first-year report. Solid, dry extracts were prepared from culture media of six Septoria isolates by filtration, evaporation, lyophilization, dialysis and further lyophilization. The powdered extracts were dissolved in minimum quantities (less than $10 \mathrm{ml}$ ) of alcohol and added to plant tissue culture media at $0,0.25,0.5$, 1.0, and $2.0 \mathrm{mg} / 1$. Extracts were added to molten agar media (i.e. above $46^{\circ} \mathrm{C}$ ). Approximately $0.5 \mathrm{~g}$ of callus was transferred to each replicate vessel of each medium treatment and allowed to grow for 28 days. Fresh weight of each callus was measured and recorded after 14 and 28 days. The weight gain was calculated as the final weight minus weight at 14 days. Data on fresh weight gain were summarized by analysis of variance.

Effects of Septoria isolate, concentration of extract, and clonal origin of the callus were significant determinants of callus weight gain. (Tables 7-18, 7-19, 7-20, and 7-21) Extracts of all Septoria isolates were inhibitory compared to controls containing no extract. Extracts of isolates 5848-103B, 5872-104B, and 5913-104C were similar and more inhibitory than extracts of isolates 5848-102A, 5848-103A, and 5848-104A. In general, NM6 callus explants gained more fresh weight than those of $\mathrm{DN} 134$ when exposed to the fungal extracts, indicating that clone DN134 was more sensitive to the extracts than NM6. The responses of the two clones to increasing doses of filtrate extracts differed. Callus growth of explants of clone DN134 was least in the presence of either 1.0 or $2.0 \mathrm{mg} / 1$, and was greater in the presence of $0.5 \mathrm{mg} / 1$ than with $0.25 \mathrm{mg} / 1$. Callus nf clone NM6 was inhibited by all doses and most strongly inhibited by the higher doses. 
Table $7-18$

EFFECT OF CLONE ON FRESH WEIGHT GAIN IN POPULUS CALLUS CULTURED IN MEDIA AMENDED WITH FUNGAL, CULTURE FILTRATE EXTRACTS FROM SEVERAL ISOLATES OF SEPTORIA MUSIVA.

\begin{tabular}{lc}
\hline Clone & Fresh wieght Gain $(\mathrm{g})^{\mathrm{a}}$ \\
\hline & \\
NM6 & $0.54 \mathrm{~b}$ \\
DN134 & $0.38 \mathrm{a}$
\end{tabular}

a/Means calculated from at least 160 observations; those followed by different letters are significantly different at $p=0.05$ by Duncan's New Multiple Range Test.

Table 7-19

EFFECT OF SEPTORIA ISOLATE ON FRESH WEIGHT GAIN IN POPULUS CALLUS CULTURED IN MEDIA AMENDED WITH FUNGAL, CULTURE FILTRATE EXTRACTS

\begin{tabular}{lc}
\hline Isolate & Fresh Weight Gain $(g)^{\text {a/ }}$ \\
\hline & \\
$5848102 \mathrm{~A}$ & $0.61 \mathrm{~b}$ \\
$5848103 \mathrm{~A}$ & $0.54 \mathrm{~b}$ \\
$5848103 \mathrm{~B}$ & $0.37 \mathrm{a}$ \\
$5848104 \mathrm{~A}$ & $0.58 \mathrm{~b}$ \\
$5872104 \mathrm{~B}$ & $0.29 \mathrm{a}$ \\
$5913104 \mathrm{C}$ & $0.36 \mathrm{a}$ \\
None & $0.76 \mathrm{C}$ \\
\hline
\end{tabular}

a/Means calculated from at least 14 observations; those followed by different letters are significantly different at $p=0.05$ by Duncan's New Multiple Range Iest. 
EFFECT OF DOSE OF FUNGAL, CULTURE FILTRATE EXTRACT ON FRESH WEIGHT GAIN OF POPULUS CALLUS CULTURED IN MEDIA SUPPLEMENTED WITH SUCH FILTRATES

PREPARED FROM SEPTORIA MUSIVA CULTURES

Filtrate Extract (mg\1) Fresh Weight Gain $(g)^{\text {a/ }}$
0.0
$0.76 \mathrm{~d}$
0.25
$0.51 \mathrm{bc}$
0.5
$0.53 c$
1.0
$0.42 \mathrm{ab}$
2.0
0.37 a

a/Mean calculated from at least 20 observations; those followed by different letters are significantly different at $p=0.05$ by Duncan's New Multiple Range Test.

Table 7-21

EFFECT OF DOSE OF CULTURE FILTRATE EXTRACT AND CLONE ON FRESH WEIGHT GAIN OF POPULUS CALLUS CULTURED ON MEDIA SUPPLEMENTED WITH SEPTORIA MUSIVA EXTRACTS

\begin{tabular}{ccc}
\hline & Mean Fresh Weight Gain $(g)^{\mathrm{a} /}$ \\
\hline Filtrate Extraci (mg\1) & \multicolumn{2}{c}{ Clone } \\
\hline & DN134 & NM6 \\
0.0 & $0.74 \mathrm{~d}$ & $0.78 \mathrm{c}$ \\
0.25 & $0.39 \mathrm{~b}$ & $0.64 \mathrm{~b}$ \\
0.5 & $0.53 \mathrm{c}$ & $0.53 \mathrm{ab}$ \\
1.0 & $0.35 \mathrm{ab}$ & $0.48 \mathrm{a}$ \\
2.0 & $0.26 \mathrm{a}$ & $0.49 \mathrm{a}$
\end{tabular}

a/Means calculated from at least 21 observations; those within columns followed by different letters are significantly different at $\mathrm{p}=0.05$ by Duncan's New Multiple Range Test. 
SOMACLONAL VARIANT PRODUCTION AND FUNGAL SPORE SCREENING

Most of the effort of creating disease-resistant clones was spent regenerating shoots and subsequently screening the population for somaclonal variants. Clones DN10, DN17, DN66, DN134, NM2, NM4, and NM6 were used as sources of explant material. Stem segments were removed from stock plants, disinfested by soaking in a dilute solution of commercial bleach, and thin sections of stem were transferred to tubes containing culture medium supplemented with growth regulators (PL2). After approximately 30 days, adventitious shoots were removed from the segments and the basal shoot-producing tissue was transferred to a fresh aliquot of similar medium. Shoots were transferred to a medium enriched with indolebutyric acid where roots formed within 21 days. Plantlets were transferred to soil conditions and maintained in a high humidity environment during acclimatization to ex vitro conditions.

When regenerated plants were between four and eight inches tall, with welldeveloped foliage, the plants were sprayed with a suspension of Septoria spores at $10^{6}$ spores per $m l$ prepared as a mixture from all isolates. Spores were harvested from cultures of infective Septoria isolates maintained on solid ks media in petri plates. Fungal isolates were maintained for up to three months in vitro when spores from these cultures were then inoculated into leaves of greenhouse stock plants. Fungal inocula were taken from diseased lesions for culture in vitro to ensure that infective cultures of the fungus were always maintained.

A total of 9600 stem segments of thil walfoul clones produced 11400 shouts that were transferred to rooting media. They flldwed /0300 pantlets in the prophlouse. 
Treatment of these plants is progressing. Plants that failed to show disease symptoms after the first treatment with spores were re-inoculated. Plants which showed no symptoms after the second treatment were selected as putative somaclonal variants with altered reaction to Septoria musiva. Only 83 plants have survived the second round of selection from the more than 10,000 tested. This rate of 0.83 percent variant production seems high when typical mutation frequencies are expected to be around 0.001 percent or 0.0001 percent. Some of the plants selected in the greenhouse will likely revert to the susceptible phenotype as the plant grows since epigenetic changes resulting from the tissue culture phase will tend not to influence the response to disease pressure.

During the final year of the program, additional plants were regenerated and exposed to fungal spore treatments. A further 4,000 plantlets were screened to expose 70 altered phenotypes. All suspected disease-resistant types were exposed to at least three treatments with fungal spores in greenhouse tests. Altered phenotypes were produced in the following clones: NM2, NM4, NM6, DN10,DN66, and DN134.

The results of the somaclonal study seem almost incomprehensible with such a high frequency of variant production (approxomately 1 percent). However, the plants have yet to be screened for disease interaction under field conditions in the northeast where the full use of the new phenotypes can be fully assessed. Further evaluation of these somaclones seems desirable and samples of several of the new types were sent to a collaborator at SUNY in syracuse for further testing. 
Manipulation of isolated plant protoplasts offers a new approach to genetic improvement of plants, particularly through creation of somatic hybrids between plant species where formation of natural, sexual hybrids is not possible. A general procedure for the isolation and culture of protoplasts is represented in figure 8-1. Experiments were initiated to assess the potential for protoplast isolation from the poplar clones collected.

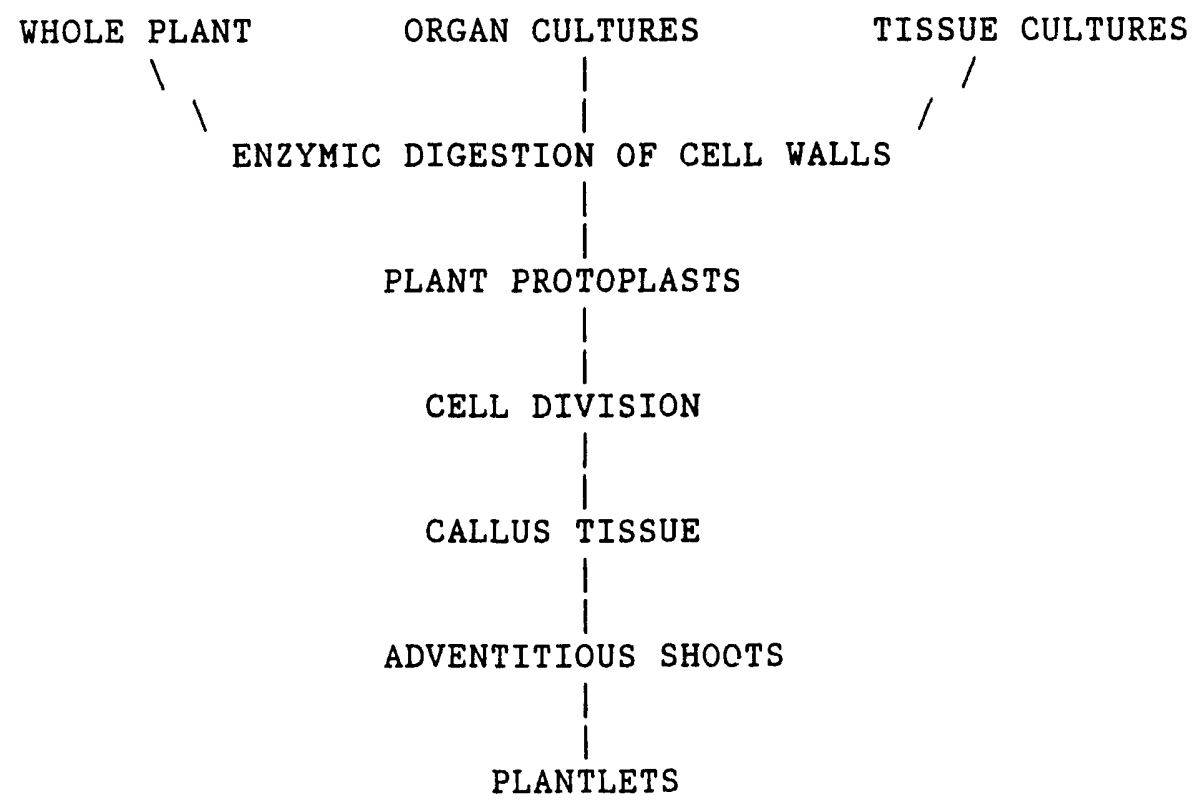

Figure 8-1. General Protocol for Isolation and Culture of Protoplasts

Initial work focused on screening mixtures of enzynes in combination with varying incubation periods in order to define a precise and reproducible protocol. The 
method developed for the production of viable protoplasts from poplar tissue involved the enzymic digestion of cell walls from finely chopped callus tissue by exposure to a mixture of 0.5 percent cellulysin and 0.1 percent macerase at $25^{\circ}$ for six-elght hours. Protoplasts were collected by filtration, centrifugation in a sucrose gradient, and transferred to a modified K8p (Kao and Michayluk 1975) medium where cell wall formation and cell division were observed.

A method for isolating of viable protoplasts of clone NM6 was developed during the first year of the program. This method was applied to callus tissue and to leaf tissue of clone NM6 to provide material for study. Several enzyme mixtures were used for callus tissue and all treatments yielded viable protoplasts that were capable of growth up to the microcallus stage. When leaf tissue from shoot-tip cultures was used for isolation, a reddish-brown coloration was observed during cell wall digestion. This colored compound, perhaps phenolic in nature, drastically decreased the viability of any protoplasts and was not suppressed when enzyme concentrations and mixtures were altered or when the osmoticum was varied.

Experiments were initiated with callus-derived protoplasts of clone NM6 to identify a suitable combination of plating density and media that promoted growth and development. A personal communication from Professor McCown at the University of Wisconsin indicated that ammonium ions $\left(\mathrm{NH}^{4}\right)$ in the culture medium could be toxic to Populus protoplasts and that the auxin 2,4-D also exerted a toxic effect. Media were formulated without $\mathrm{NH}^{4}$, and with no 2,4-D, but containing one of the auxins NAA, IAA, or NOA. No matter which particular combination of medium components was used, regeneration beyond the stage of microcalli was never observed. 


\section{SECTION 9}

DISCUSSION AND CONCLUSIONS

Poplar plants are probably the most widely used woody plant in applying modern biotechnology to forestry species. One reason the genus populus has been chosen is that many clones are available that are responsive to in vitro manipulation. Poplar was a wise choice for this type of study.

Considerable progress was made toward the goals of this research program. The quest for glyphosate-resistant poplars apparently resulted in no useful tolerance to the herbicide in any of the clones. Resistance to micromolar concentrations of the herbicide was observed in cultures of disorganized cells, but such resistance was not transmitted in a stable, useful manner to plants which regenerated from such callus.

While a transformation system for the genetic manipulation of Populus has been reported by others, it is unclear that complete plants were produced from transformed tissue. We have successfully produced a number of plants from transgenic poplar tissue and have confirmed that "new" genes were incorporated into regenerated plants. Plants resulting from transformation experiments will be grown to provide cuttings for field planting in the final year of the program.

The development of genetic transformation technology based on a disarmed binary vector system in Agrobacterium tumefasciens will greatly enhance the applicability of this fundamental genetic engineering method. Excellent results were obtained by the production of transformed plants, confirming that foreign genes were incorporated into the Populus genome. Production of genetically transformed poplar 
plants is quite feasible but is labor-and resource-intensive. This work drew on talented and skilled scientists who brought a large body of experience and expertise to the solution of technical problems. As a result, this program indicates that the transformation system is still a research tool and cannot be regarded as a generally applicable routine laboratory procedure for any populus clone. The use of the genetic transformation procedure will be greatly enhanced when genes that alter important silvicultural traits are identified and available to the scientific community for incorporation into plasmid DNA of Agrobacteria.

The information concerning the fungal strain and plant-clone specificity is indicative of the complexity of the fungus-plant interaction. Development of clones with some degree of increased resistance to attack by the pathogenic fungus s. musiva has proceeded along two distinct paths. An in vitro methodology was investigated based on selection against an extract of the fungus or fungal culture medium. This approach was valid when biological activity in culture extracts was demonstrated and such extracts influenced the growth of callus tissue of two clones. However, the protocol for extraction and collection of the active compounds, a crude toxin, was resource-intensive. Manipulation of the extract in order to successfully incorporate the hydrophobic substance into an aqueous culture medium was not always routine and straightforward. Nevertheless, a crude toxin was shown to be present in culture filtrate extracts and was shown to exert a biological response on poplar callus. The use of the selection system was limited also by an inability to promote high-frequency plant regeneration in any selected callus.

A second approach to the creation of resistant plants involved screening a large number of regenerated plants for altered susceptibility to infection by spores of 
S. musiva. Variant phenotypes were detected at a frequency of 1.0 percent. These variants failed to develop typical disease lesions after at least three treatments with suspensions of fungal spores. The screening of plants in the greenhouse to spores of the pathogen is likely to provide a more stable and applicable resistance than the screening of callus tissue, since the disease is transmitced and dispersed as spores whereas the crude toxin screen has a less obvious natural analogy. Further evaluation of the variant plants will be undertaken through cooperation with scientists at SUNY.

Development and application of protoplast technology has been included in the program since such methodology is critical in the development of novel hybrids that cannot be generated by conventional breeding. These potential hybrids may include novel unions of willow or alder with poplar. Much progress was made with the protoplast techniques and dividing callus has resulted. However, no plants were regenerated from the callus. 
Section 10

\section{LITERATURE CITED}

Ahuja, M.R. 1984. A commercialy feasible micropropagation method for aspen. Silvae Genet. 33: 174-176.

An, G., B.D. Watson, S. Stache1, M.P. Gordon and E.W. Nester. 1985. New cloning vehicles for transformation of higher plants. EMBO J. 4: 277-284.

Behnke, M. 1980. General resistance to late blight of Solanum tuberosum plants regenerated from callus resistant to culture filtrates of Phytophthora infestans. Theor. Appl. Genet. 56: 151-152.

Bousquet, J.F., B. de Franqueville, A. Kollmann, and R. Fritz. 1980. Action de la septorine, phytotoxine synthetisee par septoria nodorum, sur la Thesphorylation oxydative dans les mitochondries isolees de colephiles de Ble. Car. J. Bot. 58: 2575-2580.

Brettell, R.I.S. and E. Thomas. 1980. Reversion of Texas male sterile cytoplasmin culture to give fercile, T-toxin resistant plants. Theor. Appl. Genet. $58: 55-58$.

Carlson, P.S., B.F. Conrad and J.D. Lutz. 1984. Sorting through the variability. Hortscience, 19: 388-392.

Chaleff, R.S. 1981. Genetics of higher plants - applications of cell culture. Cambridge University Press, Cambridge, U.K.

Chaleff, R.S. 1983. Isolation of agronomicaliy useful mutants from plant cell cultures. Science, 219: 676-682.

Chalupa, V.K. 1974. Control of root and shoot formation and production of trees from poplar callus. Biol. Plantarum. 16: 316-320.

Christie, C.B. 1978. Rapid propagation of aspens and silver poplars using tissue culture techniques. Proc. Intern. Plant Prop. Soc. 28: 255-260.

DeBlock, M.D., L. Herrera-Estrella, M. Van Montague, J. Schell, axd P. Zambryski. 1984. Expression of foreign genes in regenerated plants and their progeny. EMBO J. 3: 1681-1689.

Douglas, G.C. 1985. Formation of adventitions buds in stem internodes of Populus hybrid TT32, cultured in vitro: effects of sucrose, zeatin, IAA and IBA. J. Plant Physiol. 121: 225-231.

Fillati, J.J., J. Selmer, B.H. McCown, B. Hassig, and L. Comai. 1987. Agrobacterium mediated transformation and regeneration of Populus. Mol.Gen.Genet. 200: 192-199. 
Gengenbach, B.G., C.E. Green and C.M. Donovan. 1977. Inheritance of selected pathotoxin resistance in maize plants regenerated from cell cultures. Proc. Nat1. Acad. Sci. 74: 5113-5117.

Helgeson, J.P. and B.J. Devera11. 1983. Use of tissue culture and protoplasts in plant pathology. Academic Press 193p.

Kent, S.S. and G.A. Strobel. 1976. Phytotoxin from Septoria nodorum. Trans. Br. Mycol. Soc. 67: 354-358.

King,J.E., R.J. Cook and S.C. Melville. 1983. A review of Septoria diseases of wheat and barley. Annal. Appl. Biol. 103: 345-373.

Krupinsky, J.M. and D.W. Johnson. 1.985. Septoria leaf spot of cottonwood, caragana and maple. In: Tree Disease Handbook for the Great Plains. (in press).

Lloyd, G. and B.H. McCown. 1981. Commercially feasible micropropagation of mountain laurel, Kalmia latifolia, by use of shoot tip culture. Proc. Intl. Plant Prop. Soc. 30: 336-343.

Mathes, M.C. 1964. The in vitro formation of plantlets from isolated aspen tissue. Phyton 21: 137-141.

Mehra, P.N. and G.S. Cheema. 1980. Clonal multiplication in vitro of Himalayan poplar (Populus ciliata). Phytomorphol. 30:336-343.

Merrick, M.M.A., and H.A. Collin. 1981. Selection for asulam resistance in tissue cultures of celery. P1. Sci. Lett. 20: 291-296.

Murashige, T. and F. Skoog. 1962. A revised medium for rapid growth and bioassays with tobacco tissue culture. Physiol. Plant. 15: 473-497.

Nafziger, E.D., J.M. Widholm, H.C. Steinrucken, and J.L. Killmer. 1984. Selection and characterization of a carrot cell line tolerant to glyphosate. Plant Physiol. 76: 571-574.

Singer, S. and C.N. MCDaniel. 1985. Selection of glyphosate-tolerant tobacco calli and the expression of this tolerance in regenerated plants. Plant Physiol. $78: 411-416$.

Venverloo, C.J. 1973. The formation of adventitious organs I. Cytokinin induced formation of leaves and shoots in callus cultures of Populus nigra L. 'Italica'. Acta Bot. Neer1 22: 390-398.

Winton, L.L. 1970. Shoot and tree production from aspen tissue cultures. Am.J. Bot. 57: $904-909$. 


\section{BIBLIOGRAPY}

Ahuja, M.R. 1983. Somatic cell differentiation and rapid clonal propagation of aspen. Silvae Genet. 32: 131-135.

An, G. 1985. High efficiency transformation of cultured tobacco cells. Plant Physiol. $79: 568-570$.

Anon. 1983. Glyphosate. In: Herbicide Handbook of the Weed Science Society of America, 5th edition. Weed Science Society of America. p. 258-263.

Anon. 1984. Poplar Council of the United States, Newsletter, November.

Bawa, K.S. and R.F. Stettler. 1972. Organ culture with black co:tonwood: morphogenetic response of female catkin primordia. Can. J. Bot. 50: 1627-1631.

Bevan, M. 1984. Binary Agrobacterium vectors for plant transformation. Nucleic Acids Res. 12: 8711-8721.

Bilisics, L., S. Karacsonyi, and M. Kubackova. 1979. A simple procedure of the preparation of suspensions suitable for an estimate of cell number in established tissue culture of white poplar (Populus alba L.'pyramidalis'). Biol. Plant. 21:390-394.

Bowersox, T.W. and W. Merrill. 1976. Stand density and height increment affect incidence of Septoria canker in hybrid poplar. Plant Dis. Reptr. 60: 835-837.

Brand, R., and C.J. Venverloo. 1973. The formation of adventitious organs II: the origin of buds formed on young adventitious roots of Populus nigra L. 'Italica'. Acta Bot. Neer1. 22: 399-406.

Brissette, J.C. and B.V. Barnes. 1984. Juvenile height growth of aspen species and hybrids in southeastern Michigan. San. J.For. Res. 14: 959-961.

Brisson, N., J. Paszkowski, J.R. Penswick, B. Gronenborn, I. Potrykus, and T. Hohn. 1984. Expression of a bacterial gene in plants by using a viral vector. Nature 310: 511-513.

Broertjes, C. and A.M. Van Harten. 1978. Application of mutation breeding methods in the improvement of vegetatively propagated crops. Elsevier Scientific Publish. Company, The Hague. $285 \mathrm{p}$.

Brown, C.L. and H.E. Sommer. 1982, Vegetative propagation of dicotylednous trees. In: Tissue Culture in Forestry. Eds. Bonga, J.M. and D.J. Durzan. Martinus Nijoff/Dr.W. Junk Publ. The Hague, Netherlands.

Chalupa, V.K. 1975. Induction of organogenesis in forest tree cultures. Commun. Inst. For. Czech. 9: 39-50.

Chilton, M-D. 1983. A vector for introducing new genes into plants. Sci. $10-3$ 
American 248: 50-59.

Comai, L., D. Facciotti, W.R. Hiat, G. Thompson, R.E. Rose, and D. M. Stalker. 1985. Expression in plants of a mutant aroA gene from Salmonella typhimurium confers tolerance to glyphosate. Nature 317: 741-744.

Cooper, D.T. and T.H. Filer, Jr. 1976. Resistance to Septoria leaf spot in eastern cottonwood. Plant Dis. Reptr. 60: 812-814.

Danfield, W., J. Martishus, and E. Hansen. 1983. Application date affects herbicide tolerance of hybrid poplars. NCFES-Research Note, NC-301, Forest Service USDA.

Demeritt, M.E. Jr. 1981. 50 years of hybrid poplar research in the Northeast. Proc. 27th NE Forest Tree Improvement Conf. Burlington Vt. July 1980. p166-183.

Demeritt, M.E. Jr. 1983. Six-year results of hybrid poplar clonal tests in Pennsylvania and Maryland. Proc. 28th NE Forest Tree Improvement Conf. Durham NH July 1982. p102-109.

de Framond, A.J., K.A. Barton and M-D. Chilton. 1983. Mini-Ti: A new vector strategy for plant genetic engineering. BioTech. 1: 262-269.

de Zoeten, G.A., G. Gaard, G.T. Haberlach, and J.P. Helgeson. 1982. Infection of tobacco callus by Phytophthora parasitica var. Nicotianae. Phytopathol. 72: $743-746$.

Dickmann, D., H. Phipps and D. Netzer. 1980. Cutting diameter influences early survival and growth of several Populus clones. NCFES-Research Note, NC261, Forest Service-USDA.

Douglas, G.C. 1984. Formation of adventitious buds in stem internodes of populus spp. cultured in vitro on basal medium: influence of endogenous properties of explants. J. Plant Physiol. 116: 313-321.

Duda, J, and A. Kacperska. 1983. Frost tolerance estimation in callus derived from poplar and winter rape plants using three different methods. $\underline{Z}$. Pflanzenphysiol. 111: 69-73.

Facciotti, D., J.K. O'Neal, S.Lee, and C.K. Shewmaker. 1985. Light-inducible expression of a chimeric gene in soybean tissue transformed with Agrobacterium. BioTech. 3: 241-246.

Farnum, P., R. Timmis and J.L. Kulp. 1983. Biotechnology of forest yield. Science 219: 694-702.

Filer, T.H. Jr., and C.E. Cordel1. 1983. Nursery diseases of southern hardwoods. Forest Insect and Disease Leaflet 137 USDA-Forest Service.

Filer, T.H., F.I MCCracken, C.A. Mohn, and W.K. Randa11. 1971. Septoria canker 
on nursery stock of Populus deltoides. Plant Dis. Reptr. 55: 460-463.

Fraley, R.T., S.G. Rogers, R.B. Horsch, P. Sanders, J. Flick, S. Adams, M. Bittner, L. Brand, C. Fink, J. Fry, G. Galluppi, S. Goldberg, N. Hoffman, and S. Woo. 1983. Expression of bacterial genes in plant cells. Proc. Nat1. Acad. Sci. $80: 4803-4807$.

Fraley, R.T., R.B. Horsch, A. Matzke, M-D. Chilton, W. Chilton, and P. Sanders. 1984. In vitro transformation of petunia cells by an improved method of co-cultivation with A. tumefaciens strains. Plant Mol. Biol. 3: 371-378.

Furner, I.J., G.A. Huffman, R.M. Amasino, D.J. Garfinkel, M.P. Gordon, and E.W. Nester. 1986. An Agrobacterium transformation in the evolution of the genus Nicotiana. Nature 319: 422-427.

Ghugale, D.D., D.D. Kulkarni, and R. Narasimhan. 1971. Effects of auxins and gibberellic acid on growth and differentiation of Morus alba and Pofulus nigra tissues in vitro. Indian J. Exp. Biol. 9: 381-384.

Gressel, J., N. Cohen, and H. Binding. 1984. Somatic hybridization of an atrazine resistant biotype of Solanum nigrum with Solanum tuberosum. Theor. App 1. Genet. 67: 131-134.

Griffiths, H.M. and D.G. Jones. 1985. A bioassay for predicting the resistance of wheat leaves to Septoria nodorum. Ann. Appl. Biol. 107: 293-300.

Hansen, E.A., H.A. McNeel, D.A. Netzer, H.M. Phipps, P.S. Roberts, T.F. Strong, D.N. Tolsted, and J. Zavitkovski. 1979. Short rotation intensive culture practices for northern Wisconsin. In: Proc. 16th Ann. Mtg. North Am. Poplar Council, Thompsonville, MI. Aug 14-17, 1979. p47-6:.

Hansen, E.A., and J.O. Dawson. 1982. Effects of Alnus glutinosa on hybrid Populus height growth in a short rotation intensively cultured plantation. Forest Sci. $28: 49-52$

Hansen, E.A., D.A. Netzer, and W.J. Rietveld. 1984. Site preparation for intensively cultured hybrid poplar plantations. NCFES-Research Note NC-320, Forest Service USDA.

Hansen, E.A., H.M. Phipos, and D.N. Tolsted. 1979. Rooted greenwood tip cuttings of a difficult-to-root Populus clone. Tree Planters' Notes 30:9-11.

Helmer, G., M. Casadaban, M. Beven, L. Kayes, and M-D. Chilton. 1984. A new chimeric gene as a marker for plant transformation: the expression of Escherichia coli. B-galactosidase in sunflower and tobacco cells. Bio/Tech. June 1984

Henshaw, G.G., K.K. Jha, A.R. Mehta, D.J. Shakeshaft and H.E. Street. 1966. Studies on the growth in culture of plant cells; Growth patterns in batch propagated suspension cultures. J.Exp.Bot. 17: 362-377

Hepting, G.H. 1971. Diseases of forest and shade trees of the United States. $10-5$ 
USDA Forest Service Agriculture Handbook, No. 386.

Hernalsteens, J.P., L. This-toong, J. Sche11, and M. Van Montagu. 1984. An Agrobacterium-transformed cell culture from the monocot Asparagus officinalis. EMBO J. 3: 3039-3041.

Herrera-Estrella, L., M. De Block: et al. 1983. Chimeric genes as dominant selectable markers in plant cells. EMBO J. 2: 987-995.

Hicks, T.W., and D.T. Cooper. 1982. Glyphosate application with a janitor's dustmop. Tree Planters' Notes 33: 15-16.

Hoekema, A., M.J.J. van Haaren, A.J. Fellinger, P.J.J. Hooykaas, and R.A. Schilperoort. 1985. Non-oncogenic plent vectors for use in the Agrobacterium binary system. P1. Mol. Biol. 5: 85-89.

Hooykaas-Van Slogteren, G.M.S., P.J.J. Hooykaas and R.A. Schilperoort. 1984. Expression of Ti plasmid genes in monocotyledonous plants infected with Agrobacterium tumefaciens. Nature 311: 736-764.

Ingram, D.S. 1983. Prospects and challenges for the future. In: Use of Tissue Culture and Protoplasts in Plant Pathology. Ed. Helgeson, J.P. and B.J. Deverall. Academic Press 1983.

Isebrands, J.G., A.R.Ek and R.S. Meldahl. 1982. Comparison of growth model and harvest yields of short rotation intensively cultured Populus: a case study. Can. J. For. Res. 12: 58-63.

I.A.E.A. 1977. Manual on Mutation Breeding, 2nd edition. Tech report series No. 119 . I.A.E.A. Vienna. 228 p.

Joyce, P.J., J.C. Selmer and B.H. McCown. 1986. Causes of differential responses of shoots of populus to mineral medium formulations. Hortscience 21: 262 (abstract).

Kao, K.N. and M.R. Michayluk. 1975. Nutritional requirements for growth of Vicia hajastana cells and protoplasts at a very low population density in liquid media. Planta 126:105-110

Kao, J.C., K.I. Perry and C.I. Kado. 1982. Indolacetic acid complementation and its relation to host range specifying genes on the $T i$ plasmid of Agrobacterium tumefaciens. Mol. Gen. Genet. 188: 425-432.

Kapoor, M.L. and V.K. Sharma. 1983. Evolving genetically improved clones of poplars by mutation breeding. Indian Forester 748-754.

Kechel, V.H.G. and E. Boden. 1985. Resistenzprufung an Pappeln aus Gewebekultur. Eur. J. For.Path. 15: 45-51.

Kirby, E.G. 1982. The use of in vitro techniques for genetic modification of forest trees. In: Tissue Culture in Forestry. Eds. J.M. Bonga and D.J. Durzan. Martinus Nijhoff/Dr. W Junk Pub. Boston. 369-386. 
Koncz, C., F. Kreuzaler, Z. Kalman, and J. Sche11. 1984. A simple method to transfer, integrate and study expression of foreign genes, such as chicken ovalbumin and a-actin in plant tumors. EMBO J. 3: 1029-1037.

Kouider, M., R. Skirvin, K.P.Saladin, J.O. Dawson, and J.J. Jokela. 1984. A method to culture immature embryos of populus deltoides in vitro. Can. J. For. Res. 14: 956-958.

Krupinsky, J.M., J.A. Schillinger, and A.L. Scharen. 1972. Resistance in wheat to Septoria nodorum. Crop Sci. 12: 528-530.

Ksiaxek, M., A. Wozny, and F. Mlodzianowski. 1984. Effect of $\mathrm{Pb}(\mathrm{NO} 3) 2$ on poplar tissue culture and the ultrastructural localization of lead in culture cells. For. Ecol. \& Manag. 8: 95-105.

Larkin, P.J. and W.R. Scowcroft. 1981. Somaclonal variation. A novel source of variability from cell cultures for plant improvement. Theor. Appl. Genet. $60: 197-214$.

Lester, D.T. and J.G. Berbee. 1977. Within clone variation among black poplar trees derived from callus culttre. Forest Sci. 23: 122-131.

Long, R., T.W. Bowersox, and W. Merrill. 1982. Development of Septoria canker on hybrid poplar. Phytopathol- 72: 709.(abstract).

Loper, J.E., and C.I. Kado. 1979. Host range conferred by the virulence-specifying plasmid of Agrobacterium tumefaciens. J. Bacteriol. 139: 591-596.

Maliga, P., V.A. Sidorov, A. Cspelo and L. Menczel. 1981. Induced mutations in advancing in vitro techniques. In: Induced Mutations - A tool in Plant Research. I.A.E.A. Vienna.

Matthysse, A., K.V. Holmes, and R.H.G. Gurlitz. 1981. Elaboration of cellulose fibrils by Agrobacterium tumefaciens during attachment to carrot cells. J. Bacteriol. 145: 583-595.

Matthyesse, A., and R.H.G. Gurlitz. 1982. Plant cell range for attachment of Agrobacterium tumefaciens to tissue culture cells. Phys. P1. Path. 21: $381-387$.

Matthyesse, A., K.V. Holmes, and R.H.G. Gurlitz. 1982. Binding of Agrobacterium tumefaciens to carrot protoplasts. Phys. P1. Path. 20: 27-33.

Matthysse, A. 1983. Role of bacterial cellulose fibrils in Agrobacterium tumefaciens infection. J. Bacterio1. 154: 906-915.

Matzke, M.A., M. Susani, A.N. Binns, E.D. Lewis, I. Rubenstein, and A.J.M. Matzke. 1984. Transcription of a zein gene introduced into a sunflower using a Ti plasmid vector. EMBO J. 3: 1525-1531. 
McCown, B.H. 1986. Woody ornamentals, shade trees and conifers. In: issue Culture as a Plant Production System for Horticultural Crops. Eds. 2immenan, R.H. et al. Dordecht, Netherlands. p.333-342.

McNabb, H.S.Jr., M.E. Ostry, M.A. Ritter, R.S. Sonnneliter, R.P. Yourg and K.L. Peters. 1981. Epidemiology of Septoria musiva in short rotation intensively cultured plantations of Populus hybrids in North America. Exe. XVII World Congress of IUFRO, Kyoto, Japan. Sept. 1981.

Moore, L.M., M.E. Ostry, L.F. Wilson, M.J. Morin and H.S. McNabt, Ir. 1982. Impact of Septoria canker, caused by Septoria musiva in nursery stock and first year plantation coppice. p 44-45 In: Proceedings of the Nozth American Poplar Council, 19th Annual Meeting. Eds. Zavitkovski, J. and E.A. Hansen. Rhinelander, WI.

Netzer, D.A. and E.A. Hansen. 1983. Controlling weeds in poplars by dormant season glyphosate overspray. Proc. N. Central Weed Control Conf. 38: 141-142.

Netzer, D.A. and N. Noste. 1978. Herbicide trials in intensively cultured Populus plantations in northern Wisconsin. NCFES Research Note, NC-235, Forest Service-USDA.

Ohba, K. and M. Murai. 1966. Studies in radiosensitivity of forest trees 2 . Growth and somatic mutations of Alnus, Populus and Betula species under chronic gamma irradiation in a gamma field. J. Jap. For. Soc. 48: 12-19.

Ostry, M.E., and H.S. McNabb. 1985. Susceptibility of Populus species and hybrids to disease in the north central United States. Plant Disease $69: 755-757$.

Ostry, M.E., P.E. Gerstenberger, and H.S. McNabb Jr. 1983. Control of Septoria canker in hybrid Populus nurseries. Phytopathol. 75: 837. (abstract)

Oswald, T.H., A.E. Smith, and D.V. Phillips. 1977. Herbicide tolerance developed in cell suspension cultures of perennial white clover. Can. J. Bot. 55: $1351-1358$.

Palmer, M.A. and A.L. Schipper Jr. 1979. Resistance of. poplars to Septoria leaf spot in relation to septoria canker resistance. Phytopathol. 69: 1041. (abstract).

Parsons, T.J., V.P. Sinkar, R.F. Stettler, E.W. Nester, and M.P. Gordon. 1986. Transformation of poplar by Agrobacterium tumefasciens. BioTech. 4: 533-536.

Petersen, L.A. and H.M. Phipps. 1976. Water soaking pretreatment improves rooting and early survival of hardwood cuttings of some Populus clones. Tree Planter's Notes 27: 12,22.

Phipps, H.M. and D.A. Netzer. 1981. The influence of collection time and storage temperature on Populus hardwood cutting development. Tree Planter's Notes $32: 33-36$. 
Reighard, G.L., G. Howe and J.W. Hanover. 1985. Effects of chemical weed control and seedling planting depth on survival and growth of aspen. Tree Planter's Notes $36: 3-7$.

Rood, S.B., G. Daicos and T.J. Blake. 1984. Gibberellic acid induced growth acceleration in Populus hybrids. Can. J. For. Res. 14: 850-854.

Russell. J.A. and B.H. McCown. 1986. Culture and regen ration of Populus leaf protoplasts isolated from non-seedling tissue. Plant Sci. 46: 133-142.

Russell, J.A. and B.H. McCown. 1986. Isolation, culture and regeneration of Populus masophyll protoplasts. Hort. Sci. 21: 147. (abstract).

Russe11, J.A. and B.H. McCown. 1986. Thidiazuron-stimulated shoot differentiation from protoplast-derived calli of Populus. VI Intl. Cong. Plant Tissue \& Cell Culture. Minneapolis, MN (abstract).

Saito, A. 1980. Medium for shoot formation from somatic callus tissue in Populus. J. Jap. For. Sci. 7:270-272

Saito, A. 1980. Effects of inorganic elements in the medium on shoot differentiation from Populus callus. J. Jap. For. Soc. 62: 147-149.

Saito, A. 1980. Fusion of protoplasts isolated form somatic cells of tree species. Bull. For.\& For.Prod. Res. (Japan). 309.

Schipper, A.L., Jr. 1976. Hybrid poplar disease and disease resista..ce. p. 75-80. In: Intensive Plantation Culture: Five Years Research. USD/ Forest Service Gen, Tech. Rep. NC_21.

Shain, L. and P.L. Cornelius. 1979. Quantitative inoculation of eastern cottonwood leaf tissue with Melampsora medusae under controlled conditions. Phytopathol. 69; 301-304.

Shain, L. and J.P. Miller. 1982. Pinocembrin: an antifungal compound secreted by leaf glands of eastern cottonwood. Phytopathol. 72: 877-880.

Sharma, J.K., W.A. Heather, and P. Winer. 1980. Effect of leaf maturity and shoot age of clones of Populus species on susceptibility to Melampsora larici-populina. Phytopathol. 70: 548-554.

Shields, R. 1985. Engineering herbicide resistance. Nature 317: 668.

Siegel, A. 1985. Plant-virus-based vectors for gene transfer may be of considerable use despite a presumed high error frequency during RNA synthesis. Plant Mol. Bio. 4: 327-329.

Singh, S.J. and W.A. Heather. 1982. Assesment in vitro of resistance in cultivars of Populus to Melampsora medusae Thum. leaf rust. Aust. J. For. Res. $12: 37-45$. 
Solomon, J.D., J.R. Cook, F.L. Oliverias and T.H. Filer. 1976. Insect and canker disease impact in cottonwood nurseries. Proc: Symposium on Eastern Cottonwood and Related Species. 301-307

Spielman, L.J. and M. Hubbes. 1983. Characterization of Septoria musiva isolates from Ontario and the United States. Phytopathol. 75 : 840. (abstract).

Spielman, L.J. , M. Hubbes and D. Lin. 1986. Septoria musiva on hybrid Poplar in southern Ontario. Plant Disease 70: 968-971.

Sukhapinda, K., R. Spivey, R. Simpson, and E.A. Shahin. 1987. Transgenic tomato (Lycopersicon esculentum L.) transformed with a binary vector in Agrobacterium rhizogenes: Non-chimeric origin of callus clone and low copy numbers of integrated vector T-DNA. Mol. Gen. Genet. 206: 491-497.

Thompson, G.E. 1937. Contribution to the life history and pathology of some Septoria and Marssonina leaf fungi of poplars. Unpublished. Ph.D. dissertation. Cornell University, Ithaca, NY.

Thompson, G.E. 1941. Leaf-spot diseases of poplars caused by Septoria musiva and S. populicola. Phytopathol. 31: 241-254.

Trembiay, F. M. and M. Lalonde. 1984. Requirements for in vitro propagation of seven nitrogen-fixing Alnus species. Plant Cell Tissue \& Organ Cult. 3: 189-199.

Turner, D.J. 1973. Laboratory ex -riments on 'cut bark' treatments with herbicides using cuttings of populus euroamericana 'I-78'. Weed Research 13: 91-100.

USDA. 1976. Intensive plantation culture - 5 years research. Forest Service NCFES General Technical Report \#NC-21. Ed. E.A. Hansen.

USDA. 1980. Pamphlet. How to identify and control septoria leaf spot and canker of poplar. Forest Service NCFES St. Paul, MN.

USDA. 1982. Pamphlet. How to identify ink spot of poplars. Forest Service NCFES St. Paul, MN.

USDA. 1983. Intensive plantation culture - 12 years research. Forest Service NCFES General Technical Report \#NC-91. Ed. E.A. Hansen.

Van Hoof, L., D.A. Vanden Berghe and A.J. Vlietinck. 1980. Screening of poplar trees for antibacterial, antifungal and antiviral activity. Biol. Plant. 22: 265-273.

Van Slogteren, G.M.S., J.H.C. Hoge, P.J.J. Hooykaas, and R.A. Schilperoort. 1983. Clonal analysis of heterogeneous crown gall tumor tissues induced by wild-type and shooter mutant strains of Agrobacterium tumefaciens: expression of T-DNA genes. P1. Mo1. Biol. 2: 321-333. 
Waterman, A.M. 1954. Septoria canker on poplars in the United States. USDA Circular No. 974.24 p.

Whitehead, H.C.M., and K.L. Giles. 1977. Rapid propagation of poplars by tissue culture methods. N. 2. J. For. Sci. 7: 40-43. Winata, L, and R. Harvey. 1983. Effect of glyphosate on organ formation in alfalfa callus in vitro. Dept of Agronomy, University of Wisconsin Madison, WI 53706

Winton, L.L. 1968. Plantlets from aspen tissue cultures. Science 160: 12341235 .

Winton, L.L. 1968. Initiation of friable aspen callus under different light environments. Phyton 25: 23-28.

Zavitkovski, J., E.A. Hansen, and H.A. McNeel. 1979. Nitrogen-fixing species in short rotation systems for fiber and energy production. In: Symbiotic Nitrogen Fixation in Management of Temperate Forests. Eds: J.C. Gordon et al. Oregon State University, Corvallis, OR. p.388-402.

Zeldin, E.L. and B.H. McCown. 1986. The dynamics of poplar root culture and the differentiation of shoots from cultured roots. Hortscience $21: 263$ (abstract). 

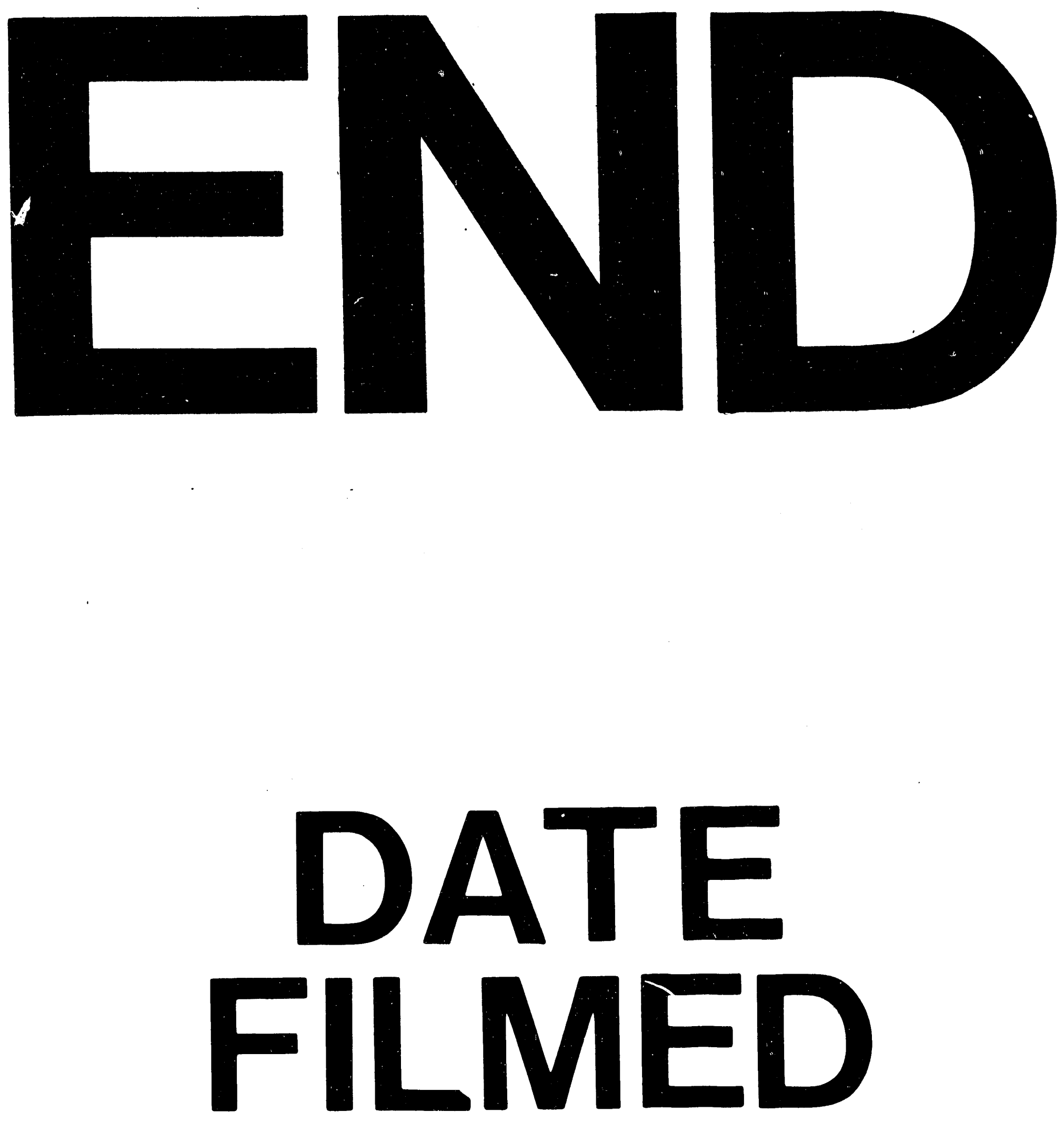

I

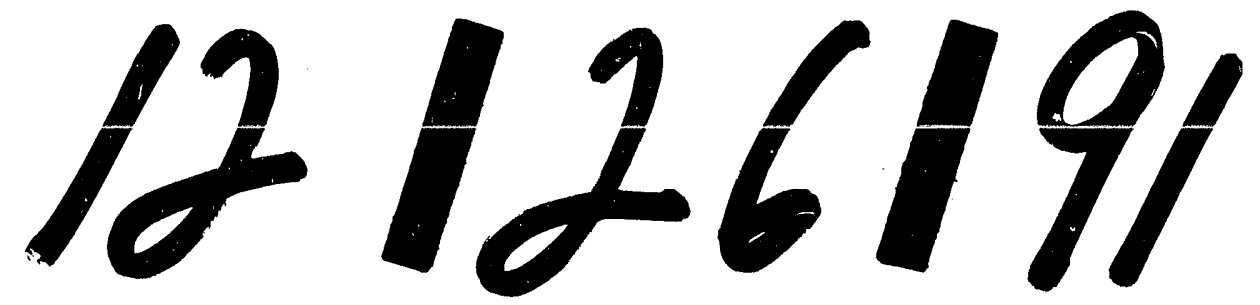


